Sterle, H. A ; Barreiro Arcos, M. L. ; Valli, E. ; Paulazo, M. A. ; Méndez Huego, S. P. ; Blidner, A. G. ; Cayrol, F. ; Klecha, A. J. ; Medina, V. A. ; Colombo L. ; Rabinovich, G. A. ; Cremaschi, G. A.

\title{
The thyroid status reprograms $T$ cell lymphoma growth and modulates immune cell frequencies
}

Posprint del documento publicado en:

Jourrnal of Molecular Medicine, 2016 Apr;94(4):417-29

Este documento está disponible en la Biblioteca Digital de la Universidad Católica Argentina, repositorio institucional desarrollado por la Biblioteca Central "San Benito Abad". Su objetivo es difundir y preservar la producción intelectual de la Institución.

La Biblioteca posee la autorización de los autores y de la editorial para su divulgación en línea.

Cómo citar el documento:

Sterle, HA, Barreiro Arcos, ML, Valli, E, et al. The thyroid status reprograms T cell lymphoma growth and modulates immune cell frequencies [en línea]. Preprint del documento publicado en Jourrnal of Molecular Medicine 2016 Apr;94(4):417-29. http://dx.doi.org/10.1007/s00109-015-1363-2.

Disponible en :http://bibliotecadigital.uca.edu.ar/repositorio/investigacion/thyroid-status-reprograms-cell.pdf [Fecha de consulta: ....] 


\section{The thyroid status reprograms T cell lymphoma growth and modulates immune cell frequencies}

H. A. Sterle 1

M. L. Barreiro Arcos 1,2

E. Valli 1

M. A. Paulazo 1

S. P. Méndez Huergo 3

A. G. Blidner 3

F. Cayrol 1

M. C. Díaz Flaqué 1

A. J. Klecha 1,5

V. A. Medina 1,5

L. Colombo 4

G. A. Rabinovich 2,3

G. A. Cremaschi $1, *, 5$

Phone +54 1143490200

Email graciela_cremaschi@uca.edu.ar

Emailgacremaschi@gmail.com

1 Instituto de Investigaciones Biomédicas (BIOMED), Consejo Nacional de Investigaciones Científicas y

Técnicas (CONICET), Facultad de Ciencias Médicas, Pontificia Universidad Católica Argentina

(UCA), Buenos Aires, Argentina

AQ1

2 Departamento de Química Biológica, Facultad de Ciencias Exactas y Naturales (FCEyN), Universidad de Buenos Aires (UBA), Buenos Aires, Argentina

3 Laboratorio de Inmunopatología, Instituto de Biología y Medicina Experimental

(IBYME), CONICET, Buenos Aires, Argentina

4 Area de Investigación, Instituto de Oncología “Angel H. Roffo”, UBA, CONICET, Buenos Aires, Argentina

5 Laboratorio de Radioisótopos, Facultad de Farmacia y Bioquímica (FFyB), UBA, Buenos Aires, Argentina

\section{Abstract}

In spite of considerable evidence on the regulation of immunity by thyroid hormones, the impact of the thyroid status in tumor immunity is poorly understood. Here, we evaluated the antitumor immune responses evoked in mice with different thyroid status (euthyroid, hyperthyroid, and hypothyroid) that developed solid tumors or metastases after inoculation of syngeneic $\mathrm{T}$ lymphoma cells. Hyperthyroid mice showed increased tumor growth along with increased expression of cell cycle regulators compared to hypothyroid and control tumor-bearing mice. However, hypothyroid mice showed a higher frequency of metastases than the other groups. Hyperthyroid mice bearing tumors displayed a lower number of tumor-infiltrating $\mathrm{T}$ lymphocytes, lower percentage of functional IFN- $\gamma$-producing $\mathrm{CD}^{+} \mathrm{T}$ cells, and higher percentage of CD19 ${ }^{+} \mathrm{B}$ cells than euthyroid tumor-bearing mice. However, no differences were found in the distribution of lymphocyte 
subpopulations in tumor-draining lymph nodes (TDLNs) or spleens among different experimental groups. Interestingly, hypothyroid TDLN showed an increased percentage of regulatory $\mathrm{T}$ (Treg) cells, while hyperthyroid mice displayed increased number and activity of splenic NK cells, which frequency declined in spleens from hypothyroid mice. Moreover, a decreased number of splenic myeloid-derived suppressor cells (MDSCs) were found in tumor-bearing hyperthyroid mice as compared to hypothyroid or euthyroid mice. MoreverAdditionally, hyperthyroid mice showed increased cytotoxic activity, which declined in hypothyroid mice. Thus, low levels of intratumoral cytotoxic activity would favor tumor local growth in hyperthyroid mice, while regional and systemic antitumor response may contribute to tumor dissemination in hypothyroid animals. Our results highlight the importance of monitoring the thyroid status in patients with $\mathrm{T}$ cell lymphomas.

\section{Key messages}

- $\mathrm{T}$ cell lymphoma phenotype is paradoxically influenced by thyroid status.

- Hyperthyroidism favors tumor growth and hypothyroidism rises tumor dissemination.

- Thyroid status affects the distribution of immune cell types in the tumor milieu.

- Thyroid status also modifies the nature of local and systemic immune responses.

\section{Keywords}

T cell lymphoma

Thyroid hormones

Proliferation

Apoptosis

Antitumor immune response

\section{Electronic supplementary material}

The online version of this article (doi: 10.1007/s00109-015-1363-2 ) contains supplementary material, which is available to authorized users.

\section{Introduction}

Recent evidence suggests that thyroid hormones (THs) are involved in cellular transformation, tumorigenesis, and metastasis, suggesting their relevant role in tumor biology [1]. Although it was demonstrated that THs regulate tumor cell physiology in vitro [2-5], the association between thyroid status and cancer has not been established. Epidemiological studies suggest tumor-promoting effects of THs, as hyperthyroidism was associated with a higher risk for ovarian [6], pancreatic [7], lung [8], and prostate [8] cancers, while hypothyroidism was associated with a slower development of invasive breast cancer [9]. However, a greater prevalence of hypothyroidism was found in patients with hepatocellular carcinoma, suggesting that TH deficit would be a potential risk factor for liver carcinogenesis $[10,11]$. Moreover, the use of levothyroxine was associated with a significantly reduced risk of colorectal cancer [12], but TH supplementation of hypothyroid patients increased the growth rate of other types of solid tumors [13]. However, a recent meta-analysis showed no significant association between hypothyroidism and the risk for breast cancer [14]. Experimental tumor models in hypothyroid or hyperthyroid animals showed no clear-cut evidence of thyroid status effects on tumor progression. Reduced growth and prolonged host survival were described in hypothyroid with respect to control tumor-bearing animals [15]. Similar findings were reported for human prostate and lung adenocarcinoma xenografts in athymic nude mice [15, 16]. Martinez-Iglesias et al. [17] showed that hypothyroidism resulted in a decreased rate of tumor growth but an increased development and number of metastasis in murine xenograft models of human hepatocarcinoma and breast cancer.

However, little information is available on the effects of thyroid status on lymphoid malignancies. Recently, we have studied the modulatory action of thyroid status on the in vivo growth of murine T lymphoma cells [18]. We found that hyperthyroid animals exhibited a higher growth rate and an earlier appearance of solid tumors than 
euthyroid or hypothyroid mice and this effect was mainly related to increased vasculogenesis [18]. Additionally, we have demonstrated that $\mathrm{TH}$-activated signaling, via its membrane receptor, promoted human $\mathrm{T}$ cell lymphoma (TCL) proliferation and angiogenesis by upregulating VEGF [19]. However, the impact of the thyroid status on tumor immunity has not been explored. This is particularly important given the impact of hypothyroidism on suppression of antibody- and cell-mediated immune responses and the contrary effects of hyperthyroidism $[20,21]$.

The immune system has a dual role in cancer development and progression. It can eliminate malignant cells via the tumor-suppressive activity of natural killer (NK) cells, conventional dendritic cells, and cytotoxic $\mathrm{T}$ lymphocytes. But, it can also promote tumor growth and spreading, mainly by downregulating the activity of antitumor effector cells; these effects are mainly mediated by plasmacytoid and tolerogenic dendritic cells, myeloid-derived suppressor cells (MDSCs), and different types of regulatory T (Treg) lymphocytes [22]. Compelling evidence suggests that immune cells infiltrating the tumors and their soluble factors contribute to the biology of many cancers and are associated with the clinical outcome of the disease. In fact, tumor infiltration by NK or Th1/CD8 cytotoxic T cells correlated with good prognosis in various cancer types [23, 24].

Despite the differences observed in $\mathrm{T}$ lymphoma growth in mice with different thyroid status, no evaluation was performed on the impact of THs in tumor dissemination and metastasis. Here, we aimed to evaluate the metastatic behavior of $\mathrm{T}$ lymphoma cells in syngeneic euthyroid, hypothyroid, and hyperthyroid mice and to study the systemic and local antitumor immune responses underlying these metastatic responses. Our results show that thyroid status has a dual effect on T lymphoma growth and dissemination, with hyperthyroidism favoring tumor local growth and hypothyroidism leading to tumor spreading. These actions were found to correlate with the regulation of $\mathrm{NK}$ and cytotoxic $\mathrm{T}$ cell function and of local and systemic expansion of immunosuppressive populations including Treg cells and MSDCs. Our results highlight the importance of monitoring the thyroid axis in patients with lymphoid malignancies.

\section{Materials and methods}

\section{Cell culture}

The tumor cell line EL-4 (ATCC) was cultured in RPMI 1640 with $10 \%$ fetal bovine serum (GIBCO) [18]. When indicated, cells were arrested by serum starvation [20]. To analyze the effects of THs, cells were treated with the combination of $100 \mathrm{nM}$ L-thyroxine (T4) and $1 \mathrm{nM}$ triiodothyronine (T3) (Sigma-Aldrich), to mimic the in vivo conditions, for the indicated time periods.

\section{Animal models}

Murine models of hyperthyroidism or hypothyroidism were developed using female C57BL/6J mice, 2-3 months old, that were bred and kept at the Instituto de Investigaciones Biomédicas (Argentina) in accordance with the ARRIVE Guidelines [25]. All experimental protocols were approved by the Institutional Committee for the Care and Use of Laboratory Animals, School of Pharmacy and Biochemistry, University of Buenos Aires.

Hyperthyroid and hypothyroid mice were obtained respectively by daily administration of $\mathrm{T} 4(0.012 \mathrm{mg} / \mathrm{ml})$ for 28 days or of the antithyroid drug propylthiouracil (PTU, $0.5 \mathrm{mg} / \mathrm{ml}$, Sigma-Aldrich) for 14 days in drinking water $[18,21]$.

\section{T cell lymphoma model}

To generate solid tumors, mice were inoculated subcutaneously with $3 \times 10^{5}$ syngeneic EL-4 cells as described [18]. Tumor length and width were measured every day using calipers, and tumor volume was calculated as $V=$ $\pi / 6 \times$ length $\times$ width $^{2}$. For the experimental metastasis test, mice were inoculated through the tail vein with $3 \times$ $10^{5}$ EL-4 cells. After 10 days, mice were killed, organs were removed and fixed in $3.7 \%$ paraformaldehyde, and tumor foci were counted.

\section{Statistical analysis}

Prism software (GraphPad) was used. Student's $t$ test for unpaired values was used to determine significance. One-way ANOVA Tukey post hoc tests were used for multiple comparisons. $P$ values of 0.05 or less were considered significant. 
Additional methods are described in Supplementary Materials and Methods.

\section{Results}

\section{Thyroid status influences tumor growth and dissemination}

To analyze the impact of the thyroid status on TCL development, we evaluated the latency, tumor volume, and metastatic dissemination on euthyroid, hyperthyroid, and hypothyroid tumor-bearing mice. Hyperthyroid mice showed high levels of THs but very low levels of TSH with respect to euthyroid animals (hyperthyroid T3 397.0 $\pm 45.1^{*} \mathrm{ng} / \mathrm{dl}$, T4 $31.5 \pm 1.3^{*} \mu \mathrm{g} / \mathrm{dl}, \mathrm{TSH}<20 \mathrm{ng} / \mathrm{ml} ; p<0.05 \mathrm{vs}$ euthyroid T3 $107.0 \pm 11.3 \mathrm{ng} / \mathrm{dl}, \mathrm{T} 46.2 \pm$ $0.8 \mu \mathrm{g} / \mathrm{dl}$, TSH $45.3 \pm 6.4 \mathrm{ng} / \mathrm{ml})$, and the contrary was observed in hypothyroid mice $(\mathrm{T} 357.6 \pm 10.3 * \mathrm{ng} / \mathrm{dl}, \mathrm{T} 4$ $<1.0 \mu \mathrm{g} / \mathrm{dl}$, TSH $62.8 \pm 5.3 \mathrm{ng} / \mathrm{ml} ;{ }^{*} p<0.05 \mathrm{vs}$ control). These animals were then subcutaneously inoculated with EL-4 T lymphoma cells. As expected from our previous results [18], hyperthyroid mice showed a significant increase in solid tumor growth compared to euthyroid animals and this effect was evident 10 days post tumor inoculation. On the other hand, hypothyroid mice showed no statistical differences in tumor growth with respect to controls (Fig. 1a, b).

Fig. 1

The thyroid status differentially modulates growth and dissemination of TCLs. a Time course increase in tumor volume among the three experimental groups and $\mathbf{b}$ tumor weight at day 10 pi of EL-4 cells $\left(3 \times 10^{5}\right)$. c Percent of mice with metastatic foci in liver or kidney after 10 days of i.v. injection of EL-4 cells $\left(3 \times 10^{5}\right)$. d Number of metastatic foci in kidney at day 10 post inoculation. Results are the mean \pm SEM of three experiments $(n=4$ mice per group); ${ }^{*} p<0.05$ versus control euthyroid mice

A

B
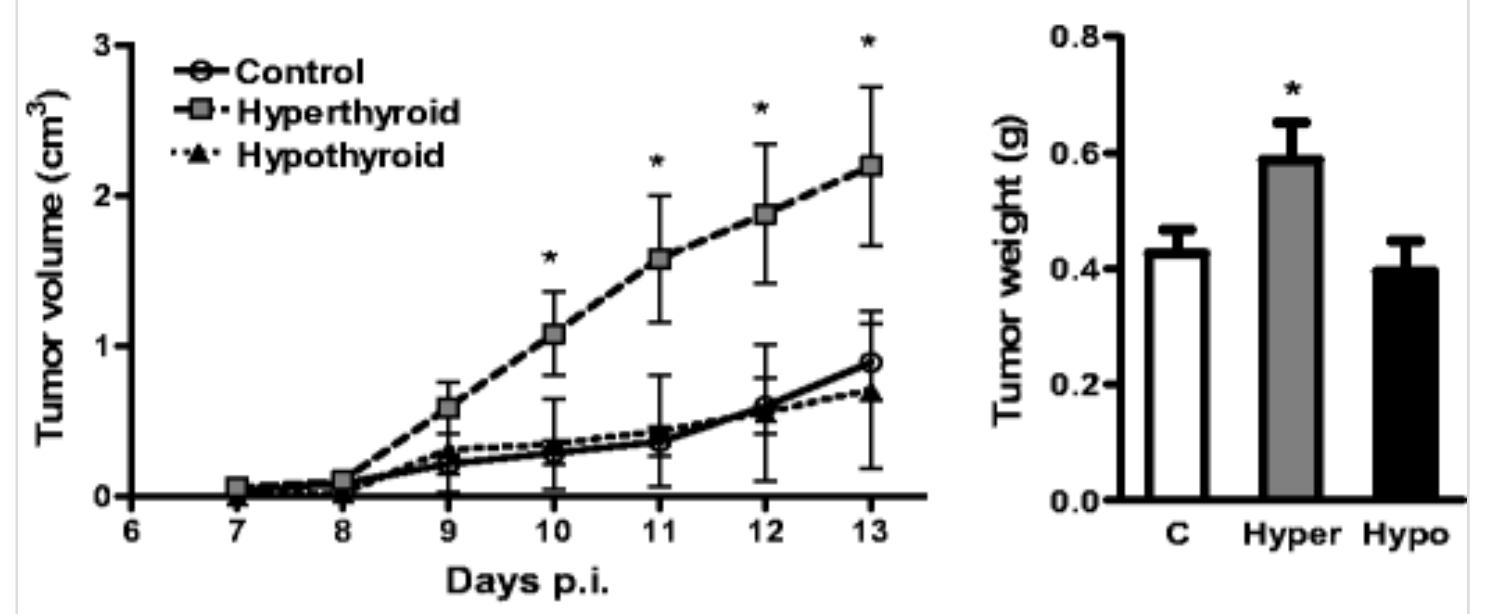

C

D

\begin{tabular}{|c|c|c|}
\hline Thyroid status & Liver & Kidney \\
\hline $\begin{array}{c}\text { Control } \\
(n=16)\end{array}$ & $68,8 \%$ & $87,5 \%$ \\
\hline $\begin{array}{c}\text { Hyperthyroid } \\
(n=19)\end{array}$ & $36,8 \%$ & $78,9 \%$ \\
\hline $\begin{array}{c}\text { Hypothyroid } \\
(n=17)\end{array}$ & $61,2 \%$ & $94,1 \%$ \\
\hline
\end{tabular}

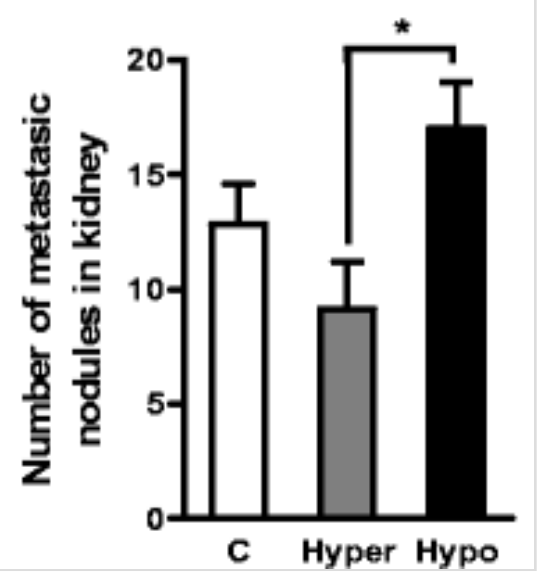

The experimental metastasis test allows the evaluation of tumor cells to survive in the circulation, extravasate, and colonize distant tissues. We analyzed EL-4 cell dissemination in the different experimental settings. The number of mice that developed metastatic nodules in the liver was lower in hyperthyroid conditions (Fig. 1c). Moreover, although all mice developed kidney metastases, the greatest number of metastatic lesions was observed in hypothyroid animals (Fig. 1d), indicating that the hypothyroid status favors the dissemination capacity of EL-4 cells.

\section{Thyroid hormones control the balance between cell proliferation and apoptosis}

To unravel the mechanisms underlying the dual effects of thyroid status on TCL, we first evaluated the influence of TH fluctuations on the balance between proliferation and apoptosis. Treatment of EL-4 cells in vitro with T3 and T4 led to an increase in proliferating cell nuclear antigen (PCNA) messenger RNA (mRNA) and protein levels (Fig. 2a, b). This effect was accompanied by an initial increase of D-type cyclins, required for the 
progression of the cell cycle from G0 to G1 phases, followed by a subsequent increase in cyclins A2 (late G1 to $\mathrm{S}$ ) and B1 (G2 to M) (Fig. 2a, b). Accordingly, hyperthyroid tumors (10 days pi) exhibited increased expression of PCNA and cyclins D1, D3, and E1 (G1 to S and S phases) (Fig. 2c, d) compared with euthyroid and hypothyroid tumors.

\section{Fig. 2}

In vitro and in vivo modulation of EL-4 cell proliferation by THs. a PCNA and cyclin mRNA by qRT-PCR at different time of TH treatment. EL-4 cells were treated with T4 $\left(1 \times 10^{-7} \mathrm{M}\right)$ and T3 $\left(1 \times 10^{-9} \mathrm{M}\right)$ for the indicated times. Data, relative to $\beta 2$-microglobulin, are the mean $\pm \mathrm{SEM}$ of at least four independent experiments; $* p<0.05$, $*^{*} p<0.01, * * * p<0.001$ versus basal (time $0 \mathrm{~h}$ ). b Immunoblot of PCNA and cyclins D3, D2, A2, and B1 in EL-4 cells treated with T4 and T3 for the indicated times. Representative bands are shown in the left, and the mean \pm SEM of at least four independent experiments is shown in the bar graph at the right; $* p<0.05$ versus basal. c PCNA and cyclin expression relative to $\beta 2$-microglobulin in tumors from euthyroid (control), hyperthyroid, and hypothyroid mice. Data are the mean \pm SEM of three independent experiments $(n=4$ mice per group) $* p<0.05$ versus control. d Representative bands of PCNA and cyclin blots and the corresponding mean \pm SEM of three independent experiments ( $n=4$ mice per group) are shown; ${ }^{*} p<0.05$ versus control
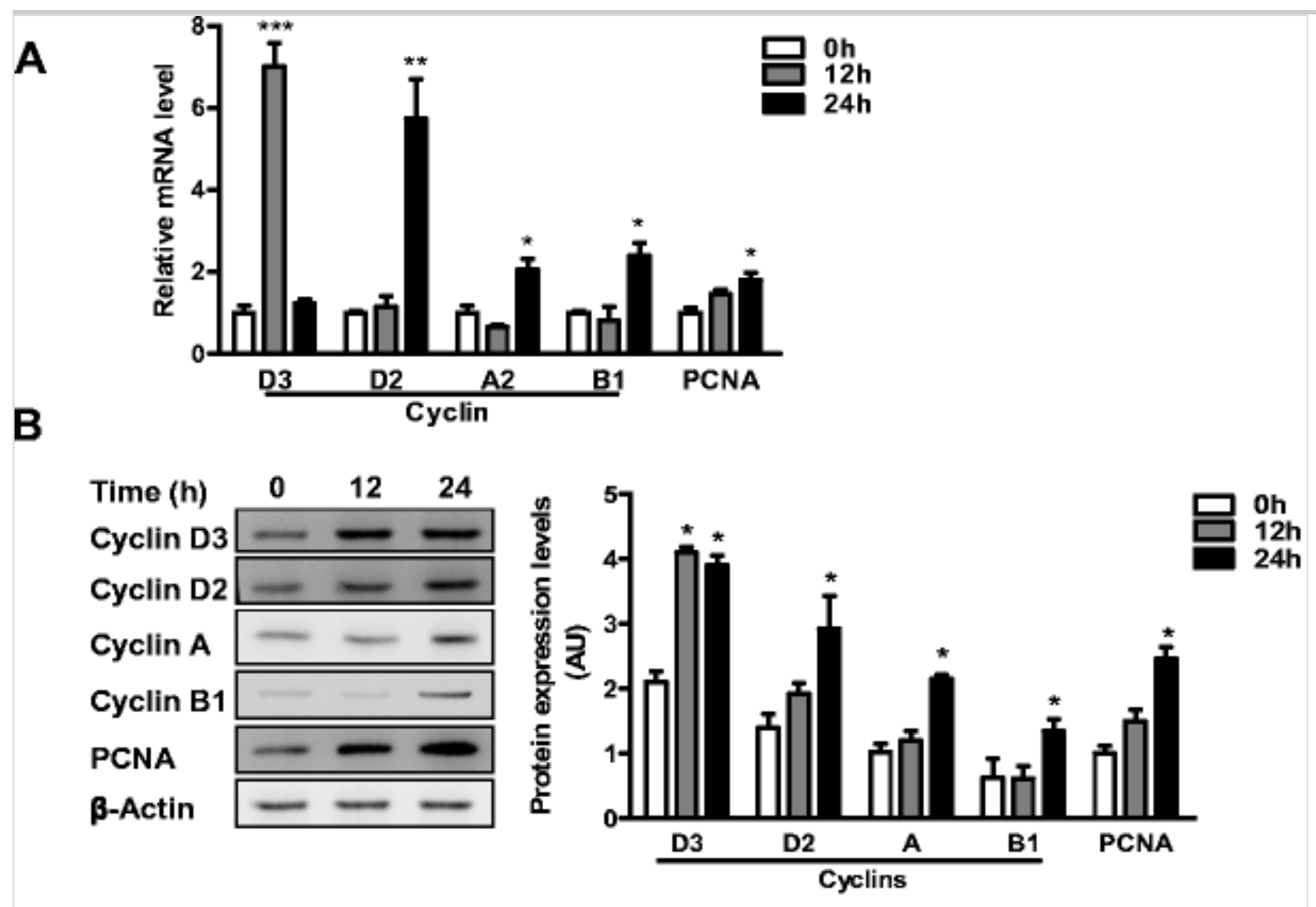

C

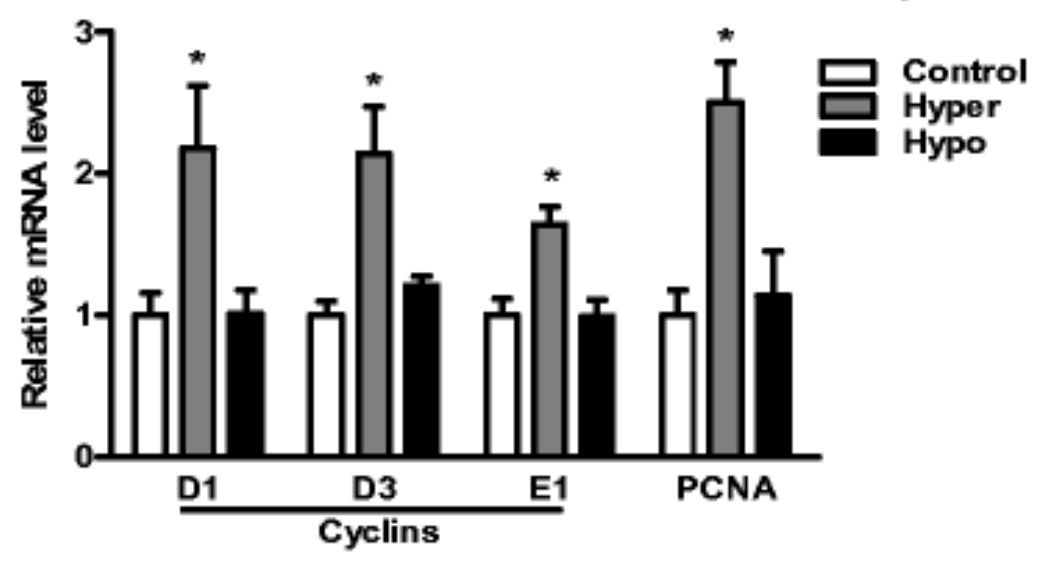

D

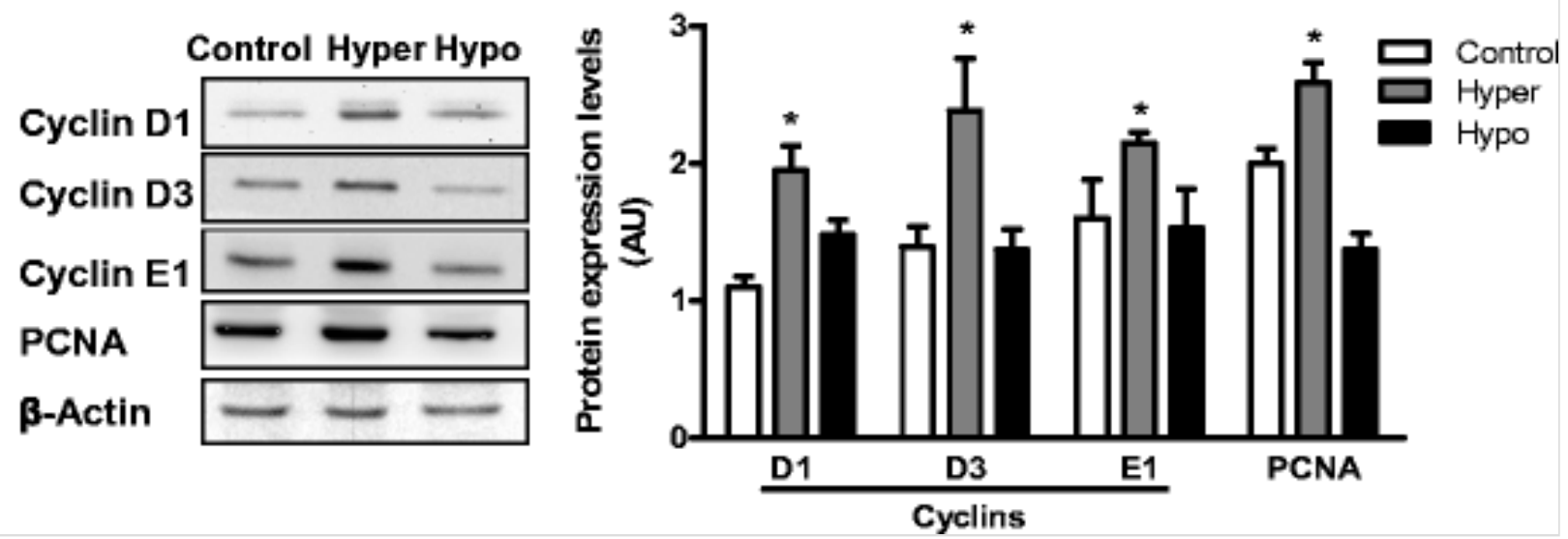

Previously, we found induction of apoptosis when T lymphoma cells were treated in vitro with T4 for more than 5 days [3]. Therefore, we evaluated apoptotic induction by long-term treatment with THs on EL-4 cells and its possible involvement in solid tumors. We found increased annexin-V/PI double staining of EL-4 cells starting from the fifth day of treatment with T3 and T4 (Fig. 3a). In addition, we observed at day 15 an increase in active 
caspase-3 (Fig. 3b) and the proapoptotic protein Bad and a decrease in the antiapoptotic protein Bcl-2 (Fig. 3c). Likewise, analysis of apoptosis indicators showed increased active caspase-3 expression (Fig. 3d) and augmented Bax mRNA (Fig. 3e) in tumors from hyperthyroid mice. Additionally, the terminal deoxynucleotidyl transferase (TdT)-mediated dUTP nick end labeling (TUNEL) assay in tumor sections showed that hyperthyroid tumors displayed increased number of apoptotic cells, mainly located contiguous to necrotic areas (Fig. 3f). However, the number of TUNEL-positive cells in the highly proliferative areas of thethese tumors was lower than in controls, suggesting a different situation in the in vivo conditions where the balance tips toward tumor cell proliferation. The number of TUNEL-positive cells in hypothyroid tumors was also higher than in controls, although they were distributed throughout the whole tissue.

\section{Fig. 3}

Regulation of EL-4 cell apoptosis by in vitro treatment with THs and in vivo control of the thyroid status. a EL-4 cells were treated in vitro with THs (T3 + T4; at a similar concentration as above) for different times and were stained with FITC-Annexin-V and propidium iodide (PI) to evaluate cell death. Representative dot plots of cells treated for $0,5,12$, or 15 days are shown. The bar graph represents the mean percent (relative to day 0 ) \pm SEM of double-positive apoptotic cells of four independent experiments; ${ }^{*} p<0.05,{ }^{* *} p<0.01$ verusversus day 0 . b Immunoblot of active caspase-3 in EL-4 cells treated or not (control) with T4 and T3 for 15 days. Representative bands are shown together with the bar graph depicting the mean optical density (relative to $\beta$-actin) \pm SEM of four experiments; ${ }^{*} p<0.05$ versus control. c Bcl-2 and Bad expression relative to $\beta 2$-microglobulin by qRT-PCR in EL4 cells treated or not (control) with T4 and T3 for 15 days. Data are the mean \pm SEM of three independent experiments; ${ }^{*} p<0.05$ versus control. d Representative immunoblots of active caspase- 3 in tumors from euthyroid (control, C), hyperthyroid, and hypothyroid mice. The mean optical density \pm SEM of three experiments are also shown; * $p<0.05$ versus control. e Levels of Bcl-2 and Bax mRNA relative to $\beta 2$-microglobulin were evaluated in tumors from mice with different thyroid status by qRT-PCR. Data are the mean \pm SEM of three experiments; ${ }^{*} p<$ 0.05 versus control. $\mathbf{f}$ Apoptotic cells as determined in tumors from euthyroid, hyperthyroid, and hypothyroid mice by terminal deoxynucleotidyltransferase-mediated dUTP nick end labeling (TUNEL) assay in proliferative and necrotic areas of representative tissue sections $(630 \times)$ from euthyroid (control), hyperthyroid, and hypothyroid mice. The mean \pm SEM number of apoptotic cells $\left(n=4\right.$ independent experiments) is also shown; ${ }^{*} p<0.05,{ }^{* *} p<$ 0.01 versus control 

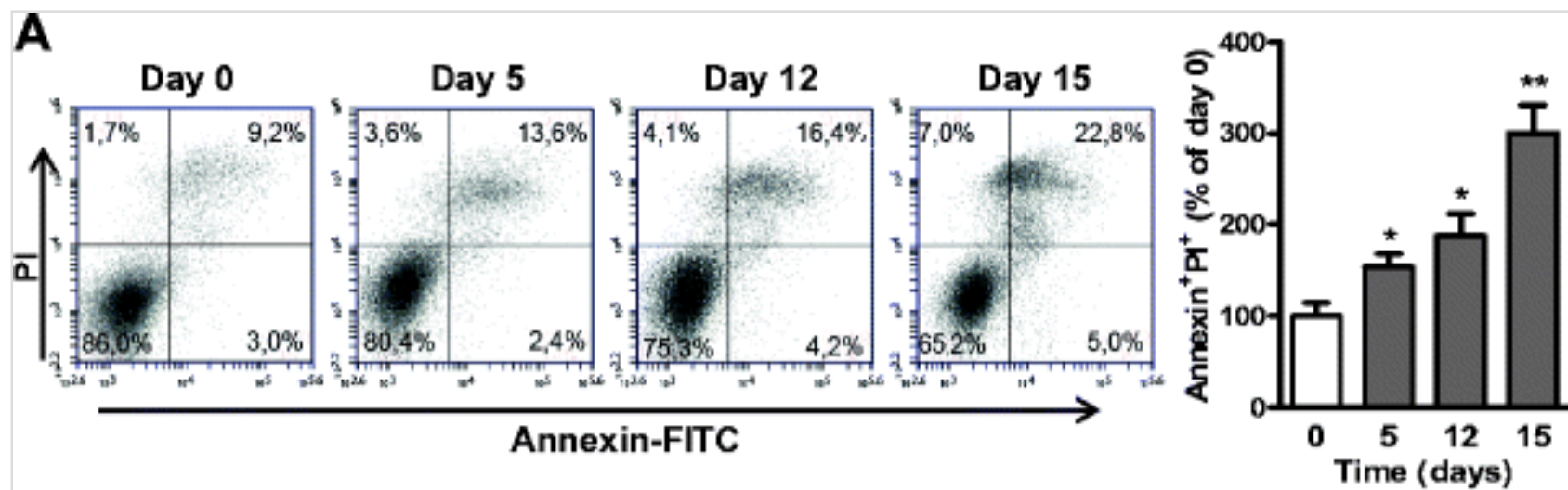

$\mathbf{B}$
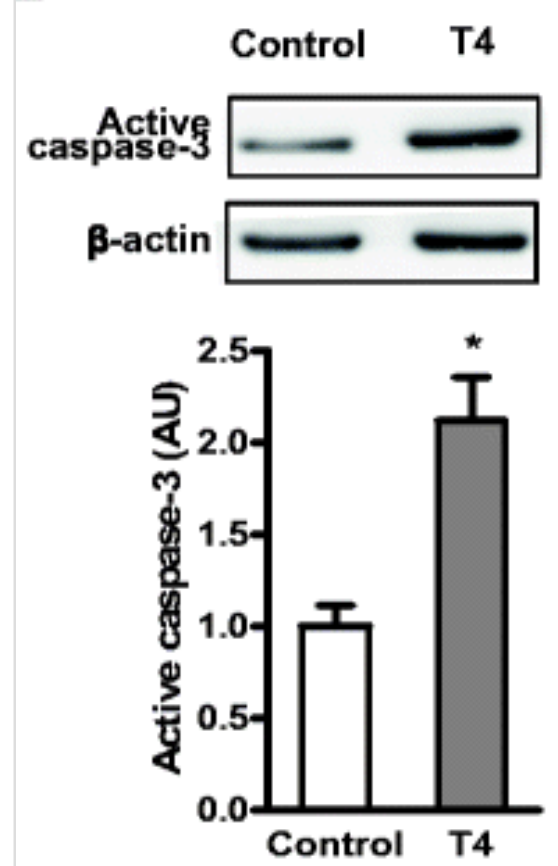

E

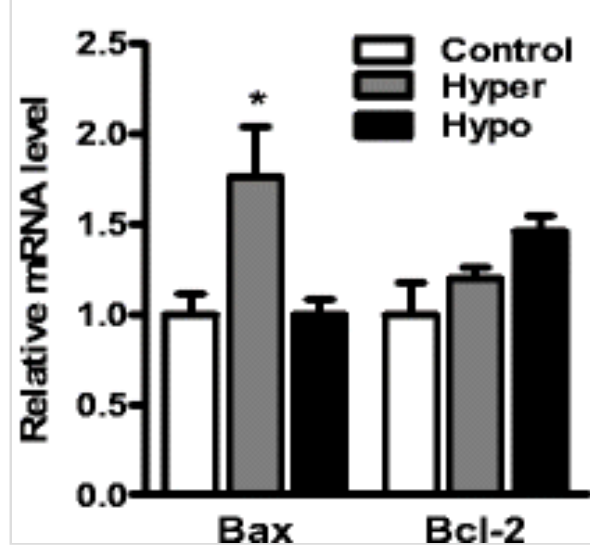

C

D

\section{Hyper Hypo}
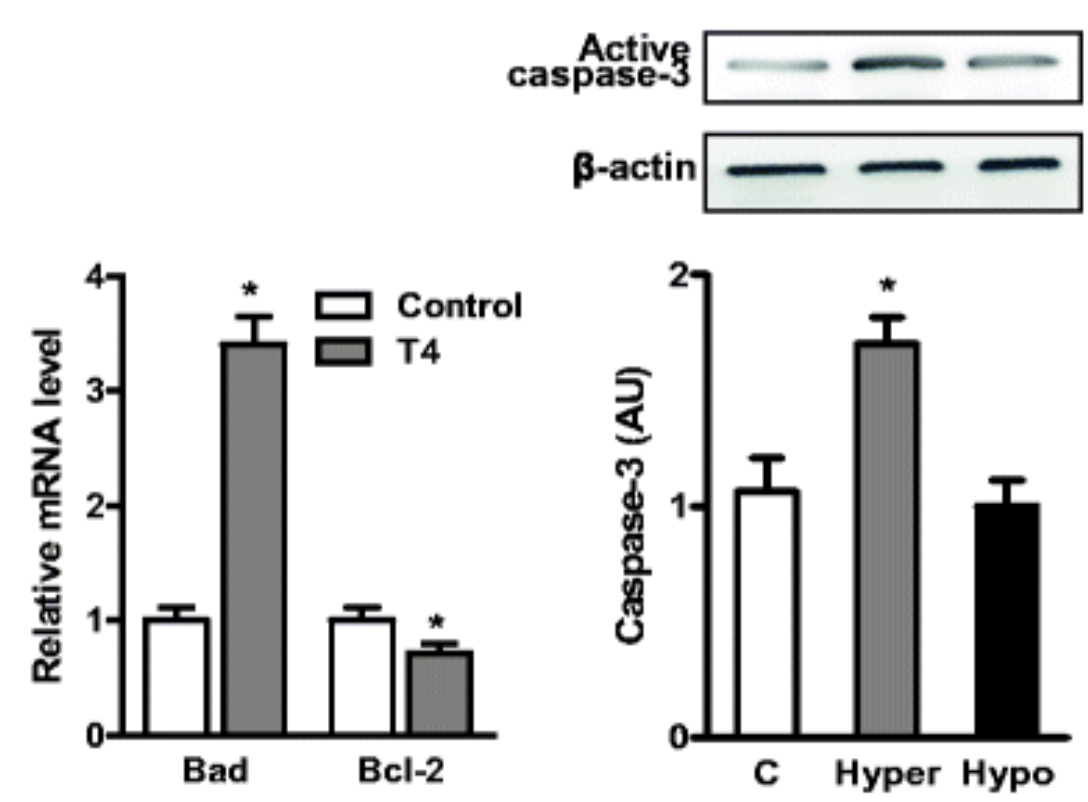

$\mathbf{F}$
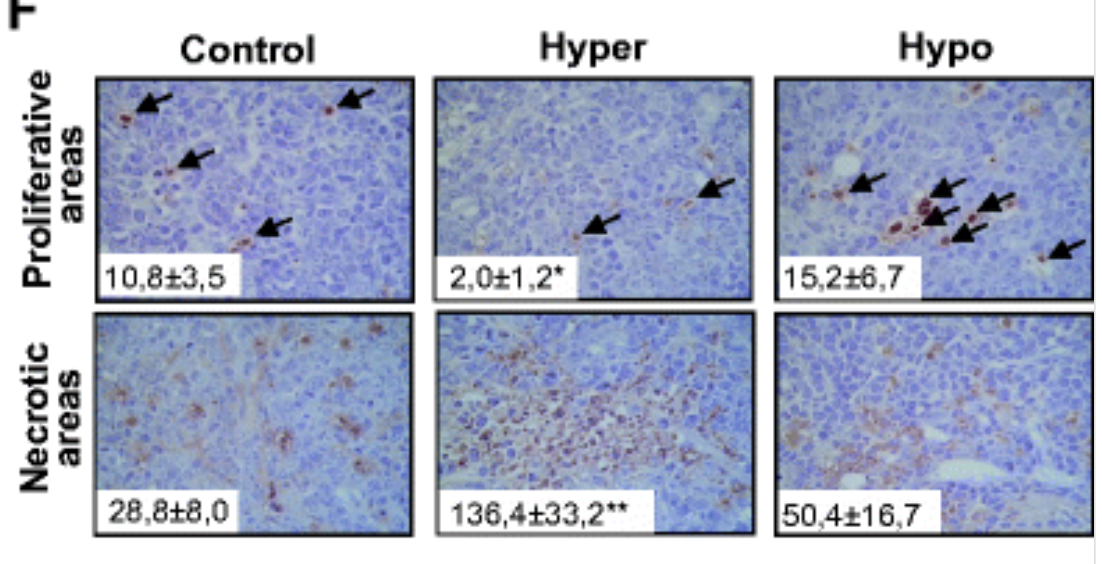

These results suggest that plasma levels of THs have a direct action on the growth of EL-4 lymphoma cells, inducing, although at different extents, both proliferation and death. Although these results are unequivocal in vitro, other factors in the tumor microenvironment may contribute to impair the proapoptotic effects of THs and to promote tumor growth in hyperthyroid animals.

\section{Effects of thyroid status in different immune cell compartments of the tumor microenvironment}

The thyroid status could also control tumor growth and metastasis through modulation of antitumor immune responses. As tumor infiltration of immune cells may correlate with good or poor prognosis depending on the magnitude and quality of these responses, we analyzed the presence of different lymphoid subpopulations in the tumor microenvironment. Noteworthy, EL-4 cells are CD4 and CD8 negative, thus precluding any confounding factor in the characterization of tumor-infiltrating lymphocytes (TILs) in the presence of tumor cells. Interestingly, the percentage of TILs was lower in hyperthyroid animals than in the other groups (Fig. 4a). Analysis of the quality of the infiltrate revealed a lower percentage of total CD8 ${ }^{+} \mathrm{T}$ cells (Figs. $4 \mathrm{~b}$ and S1A) and activated T cells (Figs. 4e and S1D) and a higher frequency of CD19 ${ }^{+}$B cells (Figs. 4d and S1C), with no changes in $\mathrm{CD}^{+} \mathrm{T}$ cell count (Figs. 4c and S1B). To confirm the functionality of CD8 ${ }^{+}$TILs, these cells were sorted from tumor cell suspensions and activated in vitro. Approximately $80 \%$ of CD $8^{+} \mathrm{T}$ cells were positive for IFN- $\gamma$ staining, with no significant differences between groups (Fig. 4f), suggesting full functionality of the $\mathrm{CD}^{+} \mathrm{T}$ cell compartment in EL-4 tumor microenvironment irrespective of the host thyroid status.

Fig. 4

Modulation of tumor-infiltrating lymphocytes (TILs) by thyroid status. $\mathrm{at}$ The presence of TILs was analyzed by flow cytometry in cell suspensions obtained from 10-day solid tumors from euthyroid (control), hyperthyroid, and hypothyroid mice. a Representative forward versus side scatter dot plot, indicating the percentage of TILs in solid 
tumors together with the mean value \pm SEM of the percentage of TILs in each group $(n=3$ independent experiments); ${ }^{*} p<0.05$ versus control; ${ }^{* *} p<0.01$ versus control $\mathbf{b}$, $\mathbf{e}$, $\mathbf{t}$, and e. Percent of $\mathrm{CD} 8^{+}(\mathbf{b}), \mathrm{CD}^{+}$(c), $\mathrm{CD} 19^{+}(\mathbf{d})$, and $\mathrm{CD} 8^{+} \mathrm{CD} 44^{\mathrm{hi}}(\mathbf{e})$ cells within the gated population of TILs. Results are the mean $\pm \mathrm{SEM}$ of three independent experiments ( $n=4$ mice per group); ${ }^{*} p<0.05$ versus control. f CD $8^{+} \mathrm{T}$ cells were sorted from tumor cell suspensions and activated with anti-CD3 and anti-CD28 mAbs plus IL-2 for $24 \mathrm{~h}$. Same number of cells were double labeled with PE-anti-CD8 and APC-anti-IFN- $\gamma$ Ab. Representative dot plots of double staining for CD8 and IFN- $\gamma$ are shown for each group

AQ3

A
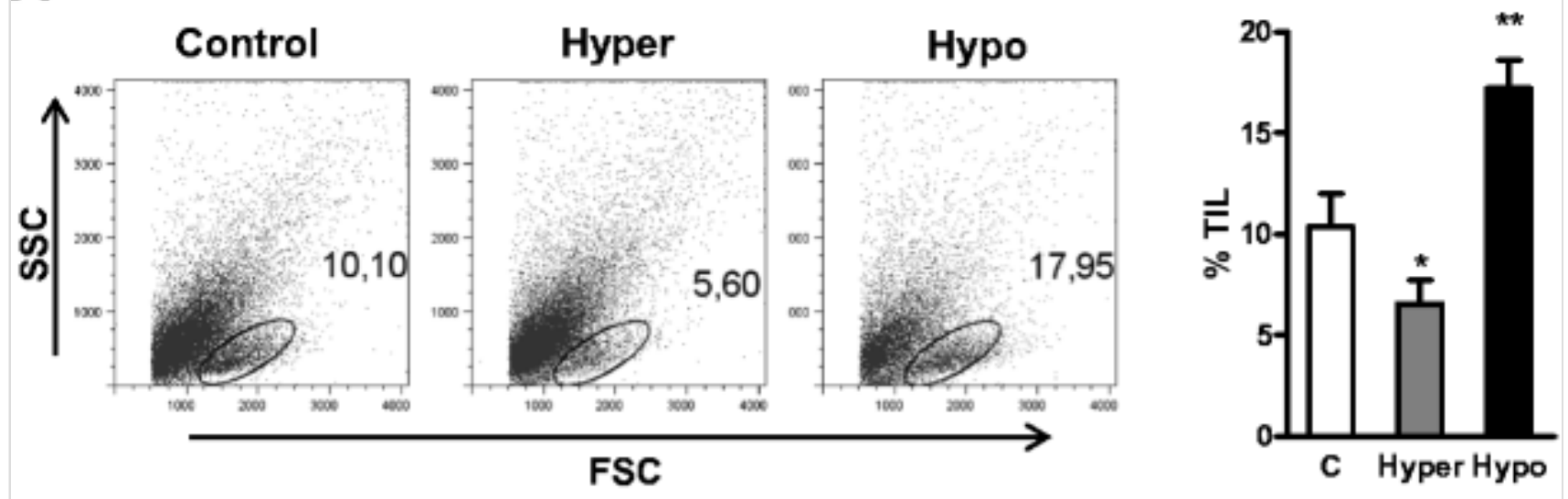

B

C

D

E
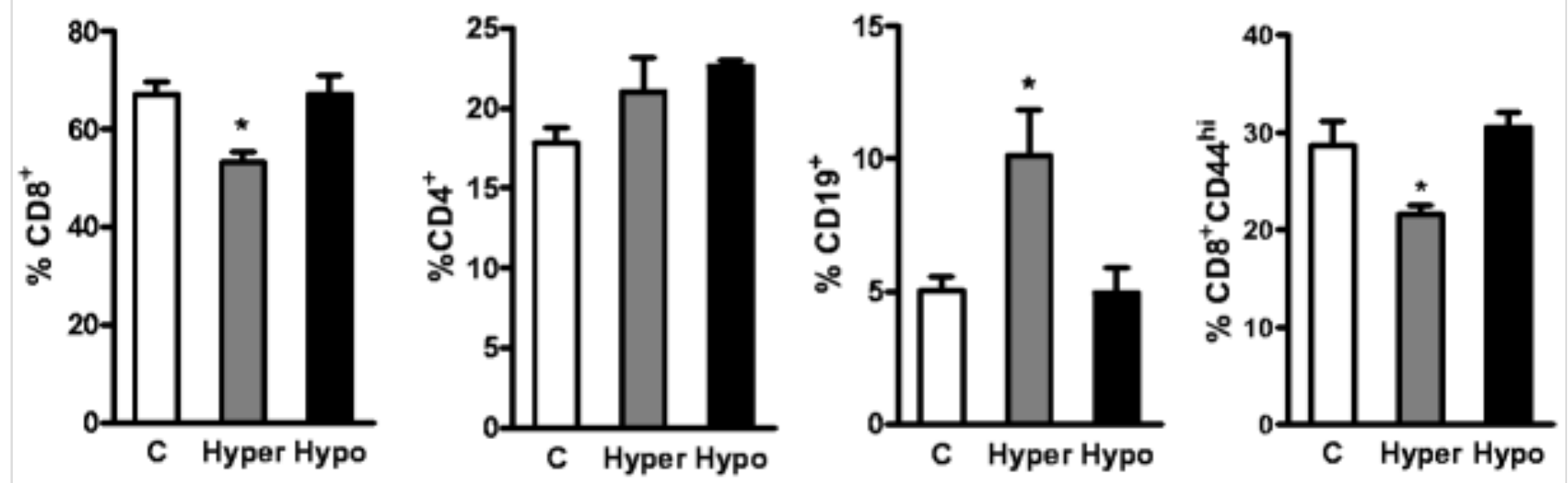

$\mathbf{F}$

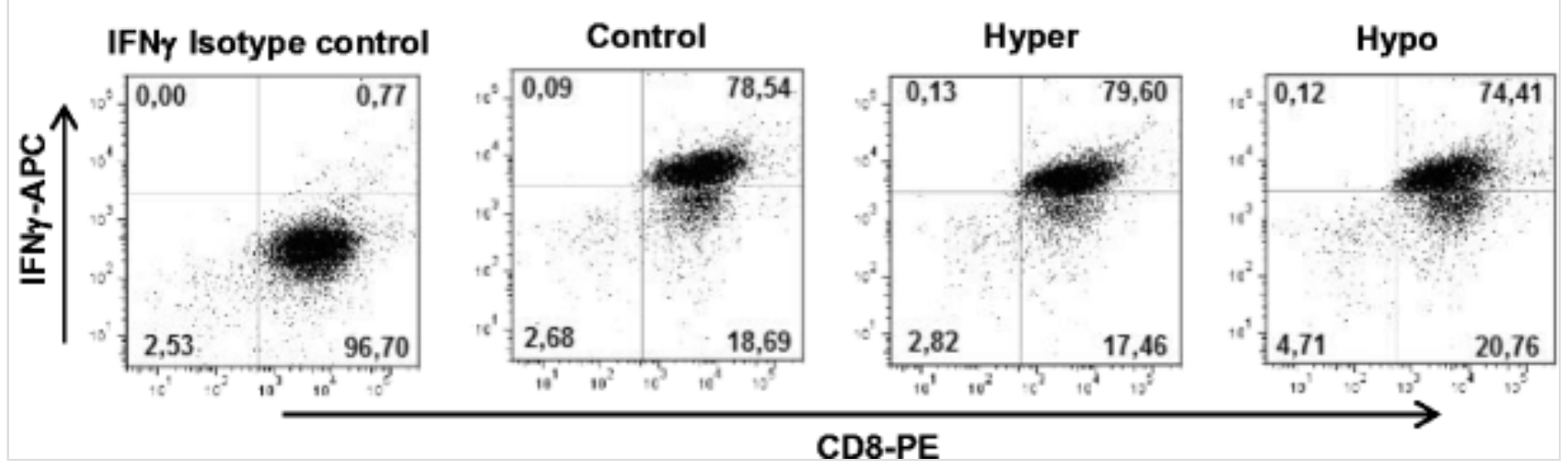

Tregs can promote tumor growth by thwarting the development of effective antitumor immune responses and promoting tumor-immune escape [26]. Similarly, MDSCs constitute a heterogeneous population of immature myeloid cells with broad immunosuppressive activity within tumor microenvironments [26]. We found no considerable differences in the frequency of MDSCs $\left(\mathrm{CD} 11 \mathrm{~b}^{+} \mathrm{Gr} 1^{+}\right)$or $\mathrm{CD} 4{ }^{+} \mathrm{CD} 25^{+} \mathrm{FoxP}^{+}$Tregs within tumor infiltrates of the different groups analyzed (Fig. S1D and S1E).

\section{Regional and systemic antitumor immune responses are affected by the thyroid status}

Establishment of metastasis is regulated, among other factors, by regional and systemic immune responses [26]. To evaluate the impact of thyroid status in the decisions between immune cell activation or tolerance to tumor antigens, we first analyzed the distribution of immune cells in tumor-draining lymph nodes (TDLNs) of control, hyperthyroid, and hypothyroid tumor-bearing mice. We could find no differences in the percentage of $\mathrm{T}\left(\mathrm{CD}^{+}\right)$ or B $\left(\mathrm{CD} 19^{+}\right)$cells within TDLN or non-draining lymph nodes (NDLN) among different experimental groups (Figs. 5a, b, S2A and S2B). However, we found a decline in the percentage of T lymphocytes in TDLN with respect to NDLN in all the groups (Fig. 5a). Similarly, we found no differences in the distribution of NK cells among different animal groups (Figs. 5c and S2C). The percentages of $\mathrm{CD} 4{ }^{+} \mathrm{CD} 25^{+} \mathrm{FoxP} 3^{+}$Tregs were similar in NDLN and TDLN in control and hyperthyroid mice; however, hypothyroid mice showed an increased percentage of these cells in TDLN, which was also higher compared to the values obtained for hyperthyroid or 
euthyroid mice (Figs. 5d and S2D). Accordingly, the percentage of activated $\mathrm{CD} 8^{+} \mathrm{T}$ cells $\left(\mathrm{CD} 8^{+} \mathrm{CD} 69^{+}\right.$or $\mathrm{CD} 8^{+} \mathrm{CD} 44^{\mathrm{hi}}$ ) was decreased in TDLN of hypothyroid mice (Figs. 5e, f, S2E and S2F). Thus, the presence of immunosuppressive Tregs in hypothyroid TDLN may contribute to tumor spreading to metastatic niches.

Fig. 5

Immune cell subsets in lymph nodes of tumor-bearing mice with different thyroid status. The frequency of different lymphocyte subpopulations was assessed in tumor-draining $(D)$ or non-draining $(N D)$ lymph nodes $(L N)$ of euthyroid (control), hyperthyroid (hyper), and hypothyroid (hypo) 10-day tumor-bearing mice. The mean percent \pm $\mathrm{SEM}$ of $\mathrm{CD}^{+} \mathrm{T}$ cells $(\mathbf{a}), \mathrm{CD} 19^{+} \mathrm{B}$ cells $(\mathbf{b}), \mathrm{CD} 3^{-} \mathrm{NK} 1.1^{+} \mathrm{NK}$ cells $(\mathbf{c}), \mathrm{CD}^{+} \mathrm{CD} 25^{+} \mathrm{FoxP} 3^{+}$Treg cells (d), $\mathrm{CD} 8^{+} \mathrm{CD} 69^{+} \mathrm{T}$ cells $(\mathbf{e})$, and $\mathrm{CD} 8^{+} \mathrm{CD} 44^{\mathrm{hi}} \mathrm{T}$ cells (f) are shown $(n=3$ independent experiments, and four mice per group); $\# p<0.05$ versus $\mathrm{ND} ;{ }^{*} p<0.05$ versus the corresponding control

A

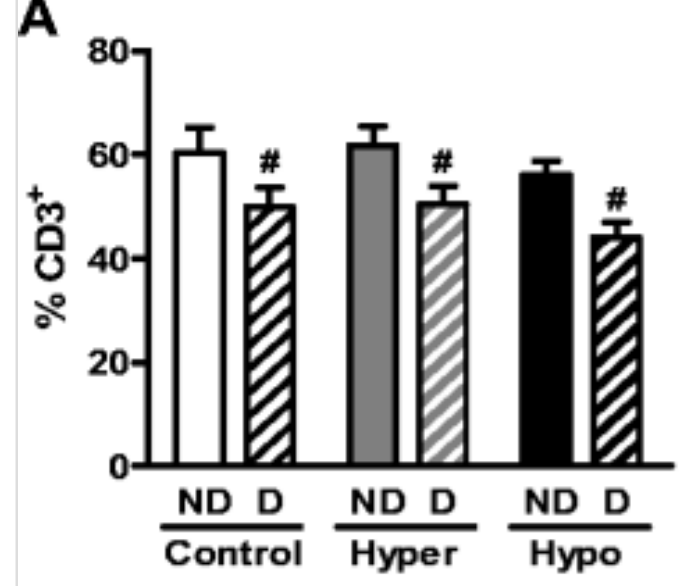

C

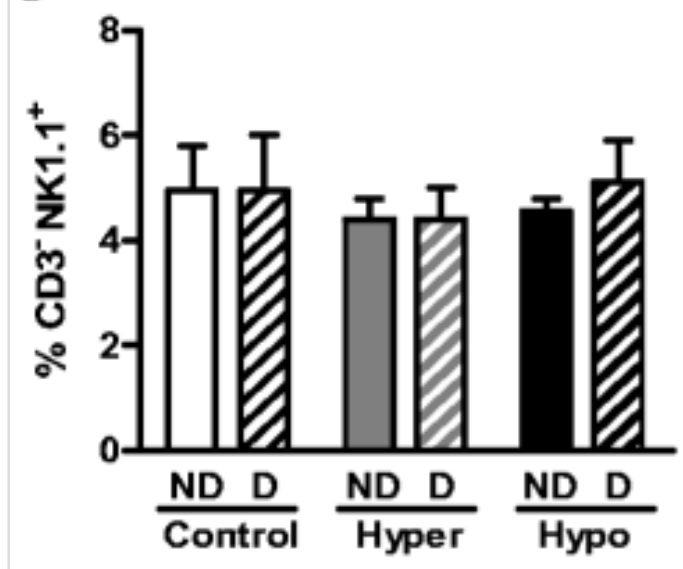

E

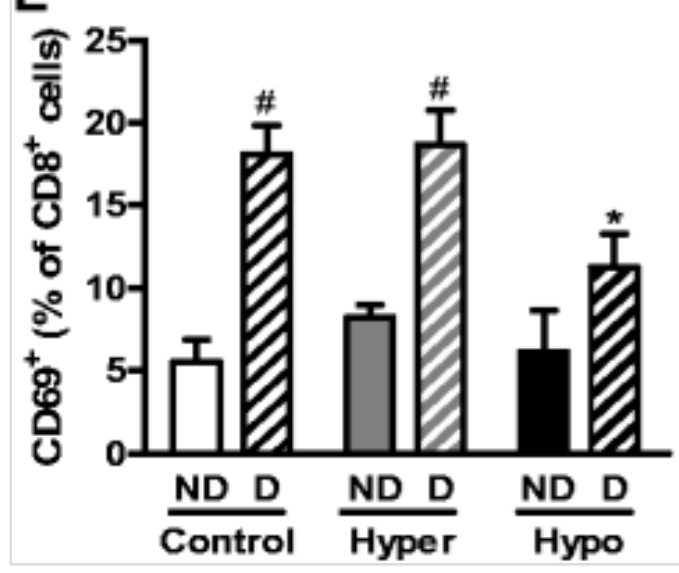

B

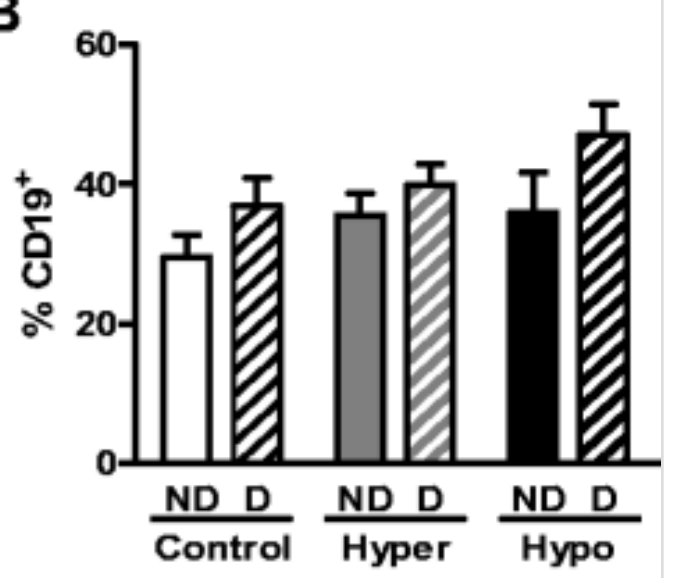

D

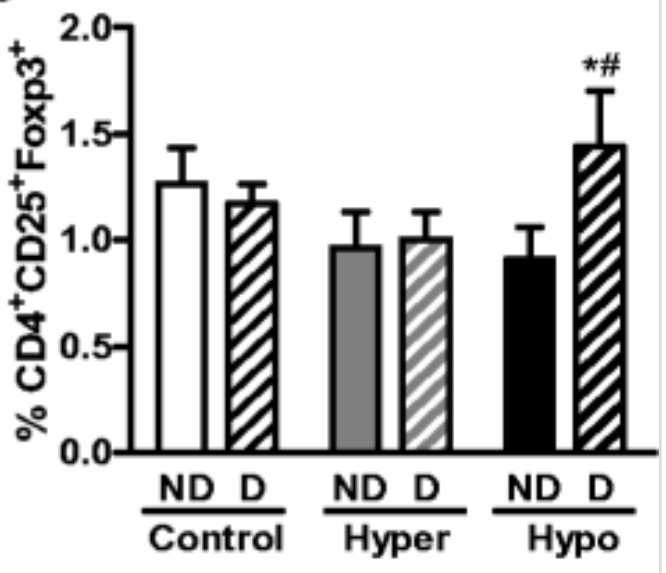

$\mathbf{F}$

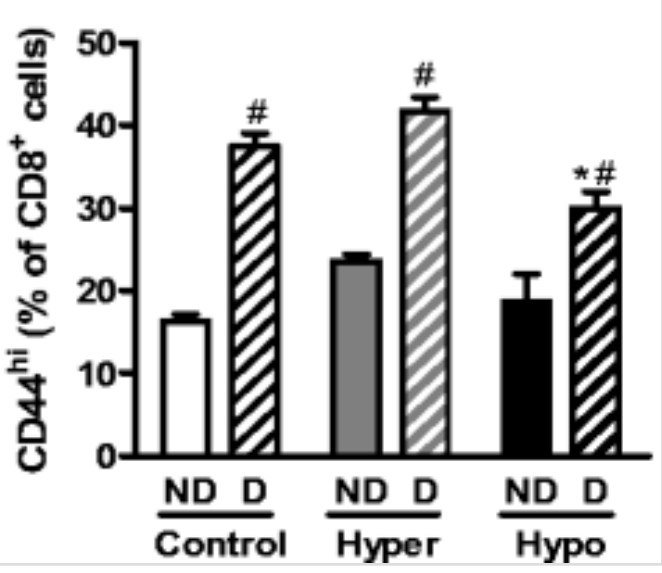

Additionally, we evaluated if the thyroid status affects the distribution and functionality of splenic immune cells in response to EL-4 cell challenge. Thus, we analyzed the distribution of lymphoid subpopulations in spleens from 10-day tumor-bearing mice. We found no differences in the percentages of $\mathrm{CD} 4^{+}$or $\mathrm{CD} 8^{+} \mathrm{T}$ cells (Figs. 6a, b, S3A and S3B), although the proportion of splenic $\mathrm{CD} 19^{+} \mathrm{B}$ cells declined in hyperthyroid and increased in hypothyroid animals (Figs. 6c and S3C). Hyperthyroid mice also showed an increased percentage of splenic NK cells, while it was decreased in hypothyroid animals (Figs. 6d and S3D). Moreover, we found that the thyroid status modulated the frequency of MDSCs in the spleen, as a decreased or increased number of these cells were found in hyperthyroid or hypothyroid animals, respectively (Figs. 6e and S3E). However, the frequency of splenic Treg cells was similar irrespective of the thyroid status (Figs. $6 \mathrm{f}$ and S3F).

Fig. 6

Phenotypic analysis of immune cell subpopulations in spleens of tumor-bearing mice with different thyroid status. Spleens from tumor-bearing mice were removed 10 days after tumor cell inoculation; single cell suspensions were obtained and analyzed by flow cytometry. Mean \pm SEM of three independent experiments ( $n=4$ mice per group) for $\mathrm{CD}^{+}(\mathbf{a})$ and $\mathrm{CD}^{+}(\mathbf{b}) \mathrm{T}$ lymphocytes, CD19 ${ }^{+} \mathrm{B}$ lymphocytes (c), CD3-NK1.1 ${ }^{+} \mathrm{NK}$ cells $(\mathbf{d}), \mathrm{Gr} 1^{+} \mathrm{CD} 11 \mathrm{~b}^{+}$ MDSCs (e), $\mathrm{CD}^{+} \mathrm{CD} 25^{+} \mathrm{FoxP}^{+}$Tregs (f), $\mathrm{CD} 8^{+} \mathrm{CD} 69^{+} \mathrm{T}$ cells $(\mathbf{g})$, and $\mathrm{CD} 8{ }^{+} \mathrm{CD} 44^{\text {hi }} \mathrm{T}$ cells $(\mathbf{h}) ;{ }^{*} p<0.05$ versus 
A

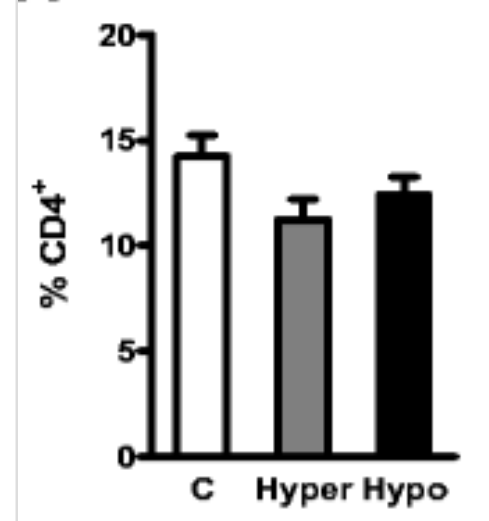

D

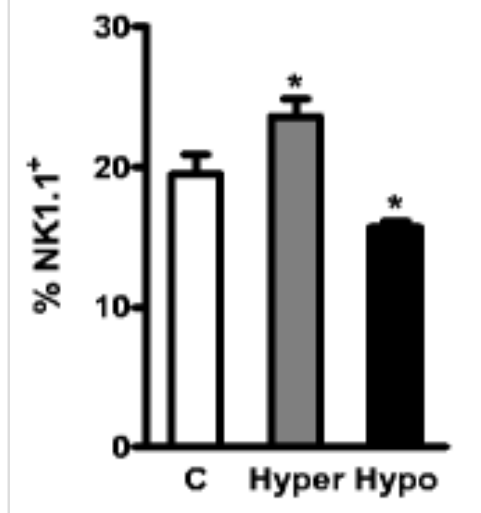

G

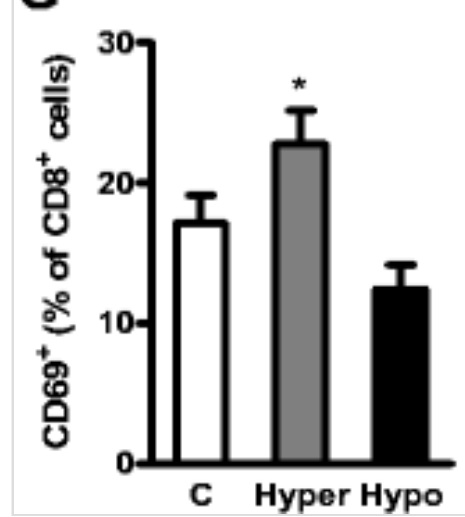

B

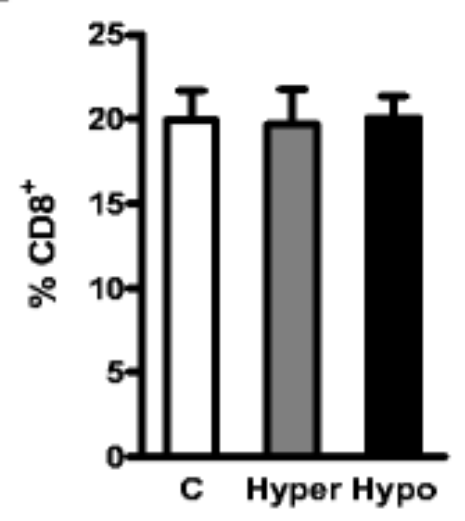

E

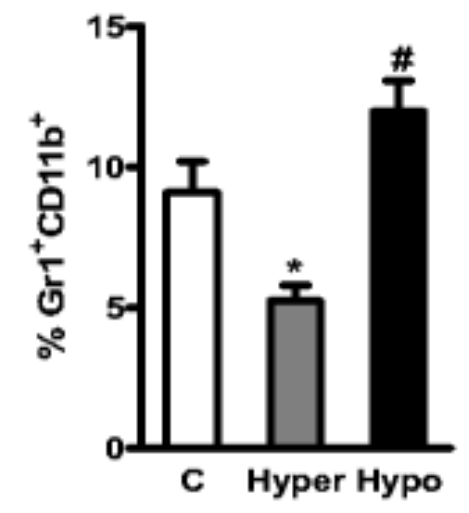

H

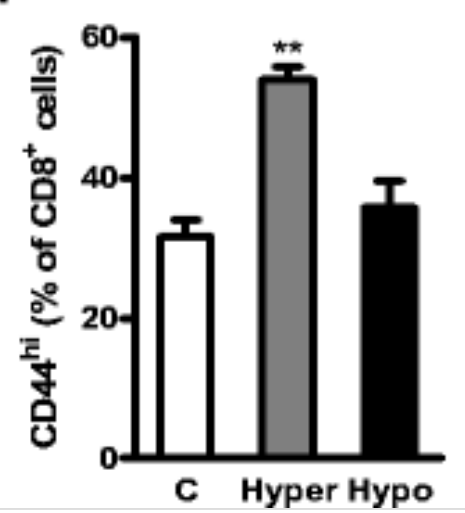

C

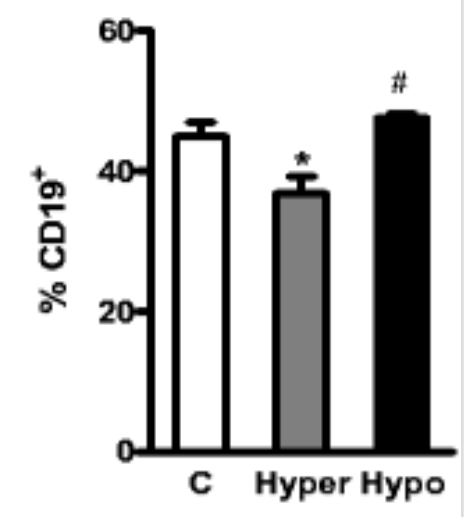

F

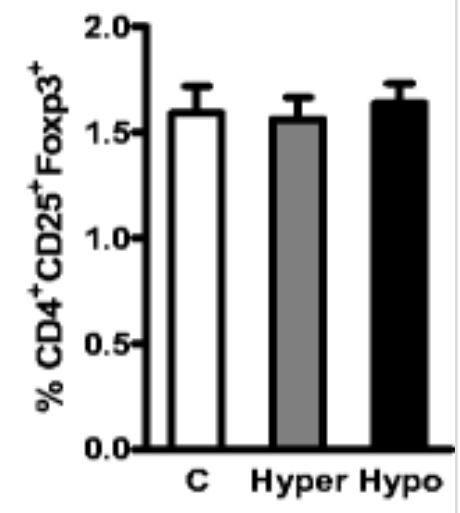

In spite of the lack of differences in the percentage of $\mathrm{CD} 8^{+} \mathrm{T}$ lymphocytes, the frequency of activated splenic $\mathrm{CD}^{+} \mathrm{T}$ cells $\left(\mathrm{CD} 69^{+}\right.$or $\mathrm{CD} 44^{\text {hi }}$ ) was increased in hyperthyroid mice (Figs. $6 \mathrm{~g}, \mathrm{~h}, \mathrm{~S} 3 \mathrm{G}$ and $\mathrm{S} 3 \mathrm{H}$ ).

Additionally, hyperthyroid mice showed increased CTL cytotoxic activity against CFSE-stained EL-4 cells, which was reduced in hypothyroid mice (Fig. 7a). Splenocytes from hyperthyroid tumor-bearing mice also showed increased NK cell-mediated cytotoxic activity against radiolabelled YAC-1 cells, while no differences were detected in hypothyroid mice compared to controls (Fig. 7b). Thus, fluctuations in the magnitude and quality of regional and systemic immune responses may explain, at least in part, the changes observed in tumor growth and dissemination in hyperthyroid and hypothyroid individuals.

Fig. 7

Modulation of non-specific and tumor-specific cytolytic activities by the thyroid status. a To analyze the specific cytotoxic activity, splenocytes from euthyroid (control), hyperthyroid, and hypothyroid tumor-bearing mice were co-cultured for 5 days with irradiated EL-4 cells and then for additional $4 \mathrm{~h}$ with CFSE-stained EL-4 cells. Finally, cells were stained with propidium iodide (PI) and analyzed by flow cytometry. Representative histograms for CFSE-gated cells and the mean \pm SEM of the cells with double staining, which were considered to be positive for lysis, are shown. b For NK cell assays, splenocytes were co-cultured during $4 \mathrm{~h}$ with YAC-1 cells which were previously labeled with $\left[{ }^{3} \mathrm{H}\right]$-thymidine. The release of radioactivity was evaluated as an indicator of cytolysis, and the mean percent of lysis \pm SEM was calculated; $* p<0.05$ versus control; $* p<0.05$ versus control; $* * p<0.01$ 
A
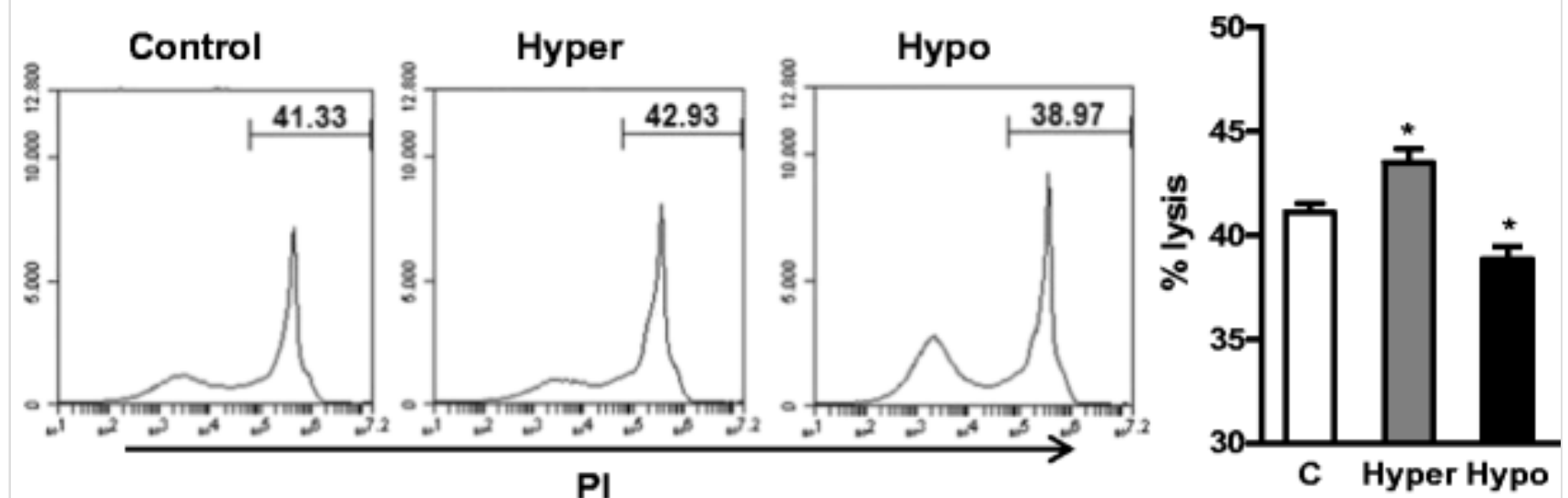

B

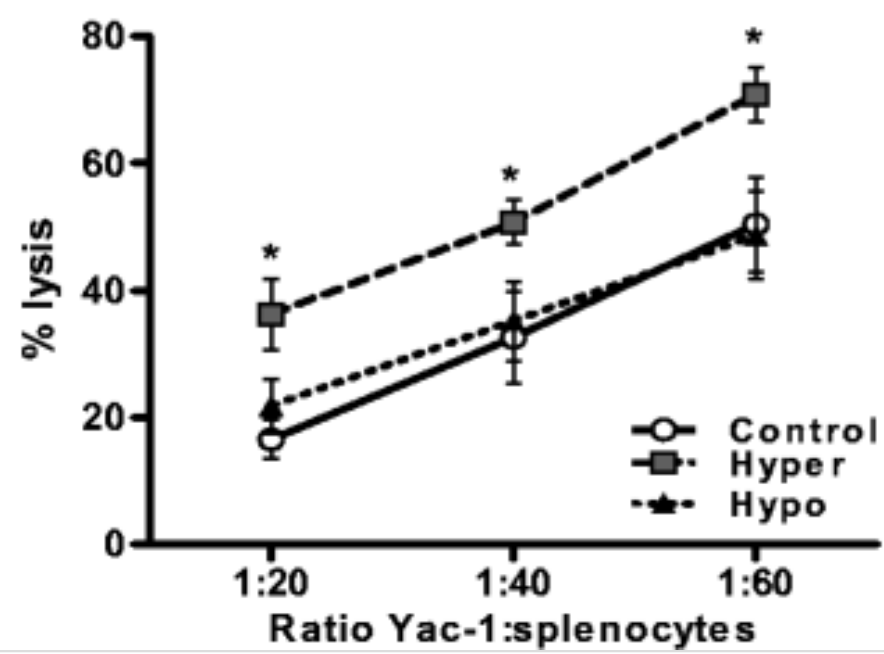

To confirm the involvement of $\mathrm{CD} 8^{+}$antitumor $\mathrm{T}$ cells in decreased tumor dissemination in hyperthyroid mice, we depleted tumor-bearing mice from $\mathrm{CD} 8^{+}$cells as described [27, 28] and analyzed metastasis spreading. Mice depleted of $\mathrm{CD}^{+} \mathrm{T}$ cells showed less than $1.7 \% \mathrm{CD}^{+}$cells in the spleen (Fig. 8a) and displayed a complete reduction of specific cytotoxic activity toward EL-4 cells (Fig. 8b). Notably, CD ${ }^{+} \mathrm{T}$ cell depletion resulted in increased frequency of mice developing liver metastasis and augmented number of renal metastasis (Fig. 8c, d), thus substantiating the contribution of effector $\mathrm{CD} 8^{+} \mathrm{T}$ cells to antitumor responses during tumor dissemination.

\section{Fig. 8}

Effect of depletion of $\mathrm{CD}^{+} \mathrm{T}$ lymphocytes in tumor growth in hyperthyroid mice. Hyperthyroid mice were i.v. inoculated with $3 \times 10^{5}$ EL-4 cells and selectively depleted (Hyper + anti-CD8) or not (Hyper) of CD8 ${ }^{+} \mathrm{T}$ cells by intraperitoneal injection with anti-CD8 $\mathrm{mAbs}$ at days $-1,2$, and 7 , relative to tumor inoculation. Spleens were removed 10 days after tumor cell inoculation, and single cell suspensions were obtained. a Representative dot plots of flow cytometry analysis of $\mathrm{CD}^{+}$and $\mathrm{CD}^{+} \mathrm{T}$ lymphocytes and mean $\pm \mathrm{SEM}$ of $\mathrm{CD} 8^{+} \mathrm{T}$ cell percentages are shown. b Specific cytotoxic activity was evaluated, and representative histograms for CFSE-gated cells and the mean $\pm \mathrm{SEM}$ of $\mathrm{IP}^{+}$cells, which were considered to be positive for lysis, are shown. c Number of mice with metastatic foci in liver or kidney after 10 days of EL-4 cells i.v. injection. $\mathbf{d}$ Number of metastatic foci in kidney at day 10 post inoculation. ${ }^{*} p<0.05$ versus control; ${ }^{* *} p<0.001$ versus control 

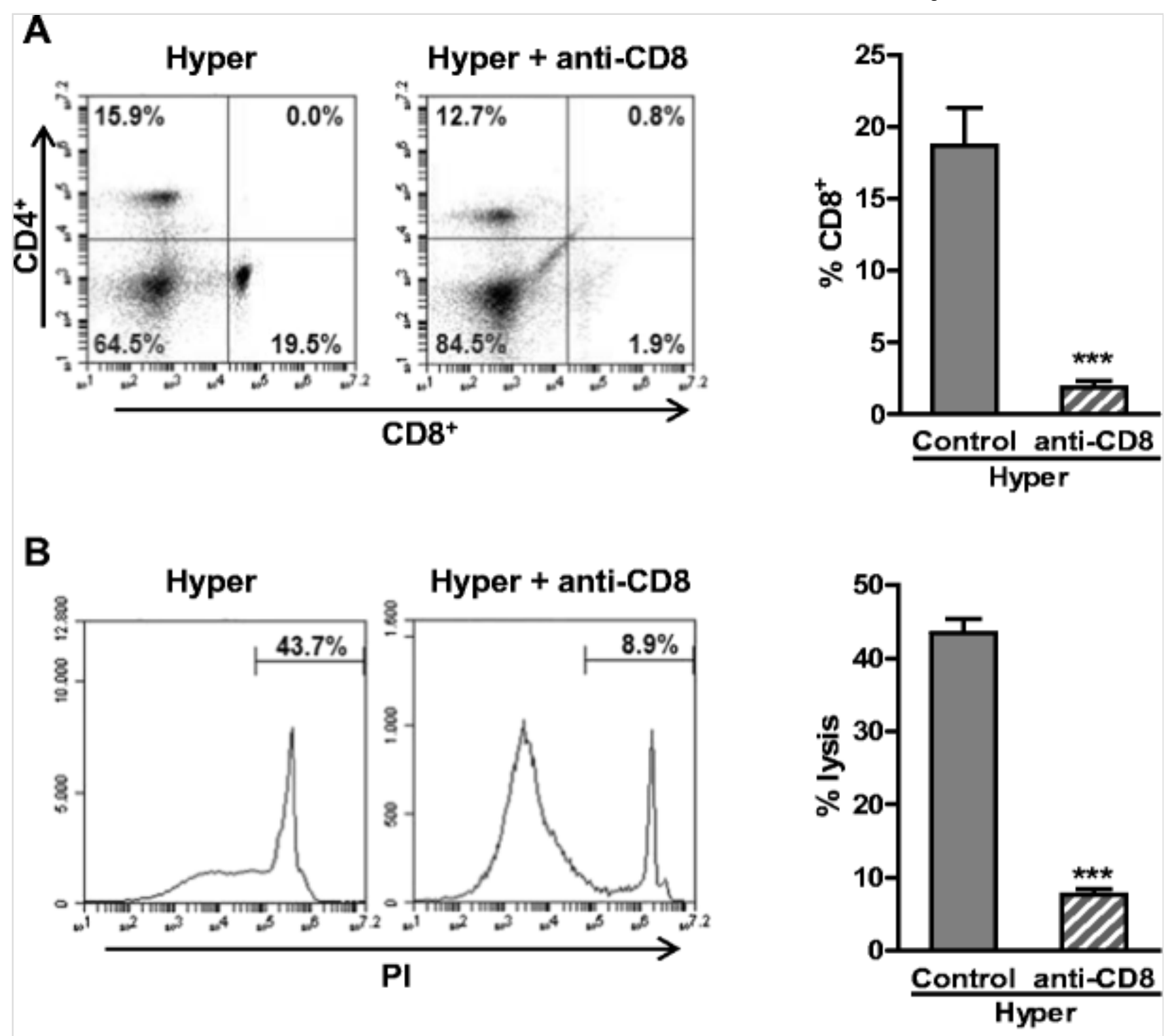

C

D

\begin{tabular}{|c|c|c|}
\hline & Liver & Kidney \\
\hline Hyper & $2 / 6$ & $5 / 6$ \\
\hline $\begin{array}{c}\text { Hyper } \\
\text { + anti-CD8 }\end{array}$ & $5 / 5$ & $5 / 5$ \\
\hline
\end{tabular}

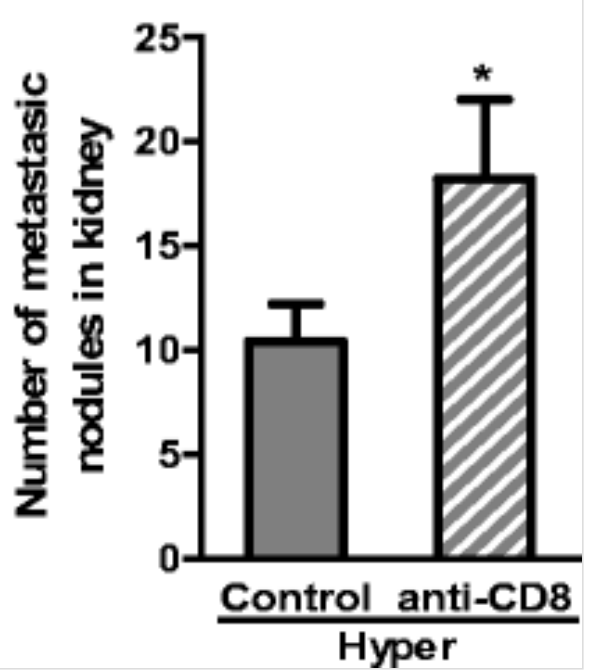

\section{Discussion}

Research over the past few years revealed a complex interplay between immune and endocrine systems during tumor growth and metastasis. This intricate connection, orchestrated by immune cells, cytokines and hormones, may influence tumor progression when individuals are exposed to physiologic or pathologic endocrine conditions [29-32]. The results presented here illustrate the influence of THs in tumor growth and metastasis of a TCL, particularly the effect of hyperthyroid and hypothyroid conditions in intrinsic (tumor proliferation and apoptosis) and extrinsic (tumor immunity) factors that govern tumor progression. We identified a paradoxical effect, in which high circulating levels of THs favor T lymphoma growth, whereas a hypothyroid condition facilitates tumor dissemination. We demonstrate that the thyroid status can selectively affect the distribution of different immune cell populations in the tumor milieu and the nature of local and systemic immune responses.

A consistent association between large tumor burden, accelerated tumor growth, and risk of metastasis has been demonstrated in several human cancers [33, 34]. However, these effects do not seem to be connected in hyperthyroid and hypothyroid mice showing increased tumor growth in response to high TH levels and accelerated tumor dissemination associated to low TH concentrations. Accordingly, Martinez-Iglesias et al. [17] showed that hypothyroidism reduces primary tumor growth but increases the formation of pulmonary metastasis in mice inoculated with human hepatocarcinoma or breast cancer cells.

To elucidate the mechanisms underlying our observations and according to our previous findings $[2,3,18$, 19], we investigated the action of TH treatment on the balance between cell proliferation and death in EL-4 cells. In vitro results showed a dual action of THs, as they exerted a proliferative effect when cells were treated for short time periods and increased tumor cell apoptosis after 5 days of treatment. Proliferative actions were 
evidenced by increased PCNA and cyclin levels, similarly to the effects observed in several human TCL cell lines upon TH addition [19]. These mechanisms were also evident in vivo in hyperthyroid tumors.

Long-term treatment of EL-4 cells with THs resulted in increased apoptosis related to an increase in active caspase- 3 and proapoptotic Bad, along with a decrease in antiapoptotic Bcl-2 protein. Thus, engagement of proapoptotic programs by THs would prevent cells to disseminate, leading to a lower number of metastasis in hyperthyroid mice. Interestingly, Mihara et al. [35] observed higher frequency of apoptotic Jurkat T cells following treatment with THs for 14 days, an effect that was accompanied by reduced Bcl-2 expression.

Accordingly, and despite their greater size, hyperthyroid tumors also showed increased number of apoptotic cells within necrotic areas, with almost no signs of apoptosis in other areas in which proliferation prevails. Probably because of this imbalance, tumors in hyperthyroid hosts displayed greater size than those growing in euthyroid or hypothyroid mice.

Compelling evidence indicates that antitumor immune responses are influenced by different signals both locally and systemically [26]. In fact, infiltration of immune cells in the tumor parenchyma is frequently an indicator of lymphoma progression [36-38], and immune cells have been described to be modulated by the thyroid status [21, 39]. Recently, Alamino et al. [40] showed that dendritic cells exposed to THs are endowed with enhanced capacity to activate antitumor responses by modulating $\mathrm{CD}^{+} \mathrm{T}$ cell survival, migration, and effector function [40]. Our results show that hyperthyroid tumors have a lower proportion of infiltrating immune cells, mainly composed of active $\mathrm{CD} 8^{+} \mathrm{T}$ lymphocytes, even though $\mathrm{CD} 4^{+} \mathrm{T}$ cells and $\mathrm{B}$ lymphocytes were also present. Interestingly, the infiltrate of hyperthyroid tumors showed a lower rate of total and activated $\mathrm{CD} 8^{+} \mathrm{T}$ cells and an increased proportion of B cells. Although the role of the B cell compartment has not been examined here in detail, the involvement of regulatory B cells leading to Treg cell activation and inhibition of antitumor responses has been described [41]. Notably, $\mathrm{CD} 8^{+} \mathrm{T}$ cells present within TILs were functional as demonstrated by their ability to produce IFN- $\gamma$ when exposed to tumor antigens. Thus, the high circulating levels of THs in hyperthyroid hosts may have an important effect on lymphocyte infiltration, particularly in the prevalence of cytotoxic T cells. Hence, impairment of the cytotoxic T cell activity in the primary tumor may favor its growth. In this regard, it has been proposed that cytotoxic and regulatory $\mathrm{T}$ cells may have positive or negative prognostic values in lymphomas, respectively [37, 42]. Moreover, Th2 and Treg cells expanded in the presence of galectin-1, a tumor-derived immunosuppressive lectin, have been shown to correlate with good prognosis in classical Hodgkin lymphoma [43].

Unexpectedly, hyperthyroid animals showed decreased metastatic dissemination despite their enhanced susceptibility toward tumor growth. Of note, EL-4 lymphoma cells have been reported to generate liver and kidney metastasis [19, 27], and changes in THs differentially influenced metastasis to these target organs. It has been estimated that only the $0.01 \%$ of tumor cells that get into circulation can survive and establish micrometastasis at distant sites because of mechanic stress, cell death, T cell, or NK cell-mediated cytotoxicity in the microcirculation [28,44]. In addition, the balance between tumor cell proliferation and apoptosis regulated by the thyroid status could also affect EL-4 cell dissemination and metastasis. In fact, the increased amounts of THs in hyperthyroid mice could induce apoptosis of circulating EL-4 cells, which would limit the metastatic establishment, as occurs following long-term treatment of EL-4 cells with THs in vitro. Supporting these findings, higher susceptibility to apoptosis was described in circulating $\mathrm{T}$ lymphocytes from patients with Graves' disease [35].

Additionally, tumor dissemination could be associated to the activation of immunosuppressive cells as described [44]. Interestingly, TDLN of hypothyroid mice displayed an increased proportion of Treg cells that would contribute to the creation of an immunosuppressive microenvironment, thus limiting antitumor immune responses. In fact, a fewer number of activated $\mathrm{CD}^{+} \mathrm{T}$ cells were found in the TDLN of these animals with respect to control or hyperthyroid mice. Recent studies revealed that some lymphoma $\mathrm{T}$ cells might adopt a Treg cell profile and Treg cells have been documented extensively in patients with different types of TCLs [45-47]. Thus, increased number of Treg cells, together with a reduced frequency of activated $\mathrm{CD} 8^{+} \mathrm{T}$ lymphocytes in TDLN of hypothyroid mice, could be suggestive of a shift toward immune cell tolerance and to an increased metastatic potential of lymphoma cells.

Interestingly, we also evaluated the distribution of immune cell subsets in spleens of tumor-bearing mice, as indicator of tumor-induced systemic immune responses. Spleens from hyperthyroid animals showed a higher proportion of NK cells with augmented cytotoxic activity compared to control mice. Remarkably, the opposite 
phenotype was found in the spleens of hypothyroid mice. However, we found no differences in the proportion of $\mathrm{CD}^{+}$or $\mathrm{CD} 8^{+} \mathrm{T}$ cells among our experimental groups. Nevertheless, we found that the thyroid status substantially regulated the activation and cytotoxic activity of splenocytes, as low circulating levels of THs inhibited the cytotoxic activity of $\mathrm{CD} 8^{+} \mathrm{T}$ cells, while high $\mathrm{TH}$ levels increased the number of activated $\mathrm{CD} 8^{+} \mathrm{T}$ cells and potentiated their cytotoxic function. These effects of THs are crucial in the regulation of EL-4 cell dissemination, as confirmed by $\mathrm{CD}^{+} \mathrm{T}$ cell depletion in hyperthyroid mice, in which the number of metastatic nodules was significantly higher than in non-depleted hyperthyroid animals, thus indicating the contribution of $\mathrm{CD} 8^{+} \mathrm{T}$ cell function to EL-4 cell metastasis.

These effects could be explained by the release of immunosuppressive cytokines and growth factors that contribute to tilt the balance toward immune tolerance either in the spleen, TDLN, and tumor microenvironment. Interestingly, we found an increased proportion of MDSCs, with no differences in the number of Treg cells in spleens from hypothyroid mice and a reduced proportion of MDSCs in hyperthyroid spleens. In this regard, very few clinical studies have linked the presence of MDSCs to lymphoma development. Tadmor et al. [48] showed increased frequency of MDSCs in the bone marrow from patients with B cell lymphomas. Also, animal models of TCLs showed increased number of MDSCs, and treatment with arginase inhibitors impaired the immunosuppressive activity of these cells, leading to augmented antitumor responses and reduction of tumor size [49].

In summary, our results indicate that the thyroid status differentially modulates antitumor immune responses and alters the balance between tumor cell proliferation and apoptosis, leading to substantial alterations in tumor growth and metastatic phenotypes of lymphoma T cells. Identification of the mechanisms by which THs shape the tumor microenvironment will contribute to the design of novel therapeutic strategies in malignant diseases.

\section{Acknowledgments}

This work was supported by the University of Buenos Aires (UBACYT 20020130100289BA) to G.A.C., the National Agency for Science and Technology (ANPCYT, PICT 2012-1328 to G.A.C. and PICT 2012-2440 to G.A.R.), and Fundación to G.A.R. We also thank Fundación Barón for kind support.

Authorship statement H.A.S., G.A.R., and G.A.C. designed research.

H.A.S., M.L.B.A., E.V., M.A.P., S.P.M.H., A.G.B., F.C., M.C.D.F., and V.A.M. performed experiments.

H.A.S., A.J.K., and L.C. developed in vivo metastasis assays.

H.A.S., G.A.R., and G.A.C. analyzed and interpreted data and performed statistical analysis.

H.A.S., G.A.R., and G.A.C. wrote the manuscript.

G.A.R. and G.A.C. supervised the study.

Compliance with ethical standards

Conflict of interest The authors declare no conflict of interests.

\section{Electronic supplementary material}

Below is the link to the electronic supplementary material.

\section{ESM 1}

(PDF $1388 \mathrm{~kb})$

\section{References}

1. Pinto M, Soares P, Ribatti D (2011) Thyroid hormone as a regulator of tumor induced angiogenesis.

Cancer Lett 301(2):119-126 
2. Barreiro Arcos ML, Sterle HA, Paulazo MA, Valli E, Klecha AJ, Isse B, Pellizas CG, Farias RN, Cremaschi GA (2011) Cooperative nongenomic and genomic actions on thyroid hormone mediatedmodulation of $\mathrm{T}$ cell proliferation involve up-regulation of thyroid hormone receptor and inducible nitric oxide synthase expression. J Cell Physiol 226(12):3208-3218

3. Barreiro Arcos ML, Sterle HA, Vercelli C, Valli E, Cayrol MF, Klecha AJ, Paulazo MA, Diaz Flaque MC, Franchi AM, Cremaschi GA (2013) Induction of apoptosis in T lymphoma cells by long-term treatment with thyroxine involves PKCzeta nitration by nitric oxide synthase. Apoptosis 18(11):1376-1390

4. Tsui KH, Hsieh WC, Lin MH, Chang PL, Juang HH (2008) Triiodothyronine modulates cell proliferation of human prostatic carcinoma cells by downregulation of the B-cell translocation gene 2. Prostate 68(6):610619

5. Cohen K, Ellis M, Khoury S, Davis PJ, Hercbergs A, Ashur-Fabian O (2011) Thyroid hormone is a MAPK-dependent growth factor for human myeloma cells acting via alphavbeta3 integrin. Mol Cancer Res 9(10):1385-1394

6. Ness RB, Grisso JA, Cottreau C, Klapper J, Vergona R, Wheeler JE, Morgan M, Schlesselman JJ (2000) Factors related to inflammation of the ovarian epithelium and risk of ovarian cancer. Epidemiology 11(2):111-117

7. Ko AH, Wang F, Holly EA (2007) Pancreatic cancer and medical history in a population-based casecontrol study in the San Francisco Bay Area, California. Cancer Causes Control 18(8):809-819

8. Hellevik AI, Asvold BO, Bjoro T, Romundstad PR, Nilsen TI, Vatten LJ (2009) Thyroid function and cancer risk: a prospective population study. Cancer Epidemiol Biomarkers Prev 18(2):570-574

9. Cristofanilli M, Yamamura Y, Kau SW, Bevers T, Strom S, Patangan M, Hsu L, Krishnamurthy S, Theriault RL, Hortobagyi GN (2005) Thyroid hormone and breast carcinoma. Primary hypothyroidism is associated with a reduced incidence of primary breast carcinoma. Cancer 103(6):1122-1128

10. Reddy A, Dash C, Leerapun A, Mettler TA, Stadheim LM, Lazaridis KN, Roberts RO, Roberts LR (2007) Hypothyroidism: a possible risk factor for liver cancer in patients with no known underlying cause of liver disease. Clin Gastroenterol Hepatol 5(1):118-123

11. Hassan MM, Kaseb A, Li D, Patt YZ, Vauthey JN, Thomas MB, Curley SA, Spitz MR, Sherman SI, Abdalla EK et al (2009) Association between hypothyroidism and hepatocellular carcinoma: a case-control study in the United States. Hepatology 49(5):1563-1570

12. Rennert G, Rennert HS, Pinchev M, Gruber SB (2010) A case-control study of levothyroxine and the risk of colorectal cancer. J Natl Cancer Inst 102(8):568-572

13. Hercbergs AH, Ashur-Fabian O, Garfield D (2010) Thyroid hormones and cancer: clinical studies of hypothyroidism in oncology. Curr Opin Endocrinol Diabetes Obes 17:432-436

14. Angelousi AG, Anagnostou VK, Stamatakos MK, Georgiopoulos GA, Kontzoglou KC (2012) Mechanisms in endocrinology: primary HT and risk for breast cancer: a systematic review and meta-analysis. Eur J Endocrinol 17(5):432-436

15. Moeller LC, Fuhrer D (2013) Thyroid hormone, thyroid hormone receptors, and cancer: a clinical perspective. Endocr Relat Cancer 20(2):R19-R29

16. Theodossiou C, Schwarzenberger P (2000) Propylthiouracil reduces xenograft tumor growth in an athymic nude mouse prostate cancer model. Am J Med Sci 319(2):96-99 
18. Sterle HA, Valli E, Cayrol F, Paulazo MA, Martinel Lamas DJ, Diaz Flaque MC, Klecha AJ, Colombo L, Medina VA, Cremaschi GA et al (2014) Thyroid status modulates T lymphoma growth via cell cycle regulatory proteins and angiogenesis. J Endocrinol 222(2):243-255

19. Cayrol F, Diaz Flaque MC, Fernando T, Yang SN, Sterle HA, Bolontrade M, Amoros M, Isse B, Farias $\mathrm{RN}$, Ahn $\mathrm{H}$ et al (2015) Integrin alphavbeta3 acting as membrane receptor for thyroid hormones mediates angiogenesis in malignant $\mathrm{T}$ cells. Blood 125(5):841-851

20. Barreiro Arcos ML, Gorelik G, Klecha A, Genaro AM, Cremaschi GA (2006) Thyroid hormones increase inducible nitric oxide synthase gene expression downstream from PKC-zeta in murine tumor T lymphocytes. Am J Physiol Cell Physiol 291(2):C327-C336

21. Klecha AJ, Genaro AM, Gorelik G, Barreiro Arcos ML, Silberman DM, Schuman M, Garcia SI, Pirola C, Cremaschi GA (2006) Integrative study of hypothalamus-pituitary-thyroid-immune system interaction: thyroid hormone-mediated modulation of lymphocyte activity through the protein kinase $\mathrm{C}$ signaling pathway. J Endocrinol 189(1):45-55

22. Gutkin DW, Shurin MR (2014) Clinical evaluation of systemic and local immune responses in cancer: time for integration. Cancer Immunol Immunother 63(1):45-57

23. Fridman WH, Pages F, Sautes-Fridman C, Galon J (2012) The immune contexture in human tumours: impact on clinical outcome. Nat Rev Cancer 12(4):298-306

24. Rabinovich GA, Gabrilovich D, Sotomayor EM (2007) Immunosuppressive strategies that are mediated by tumor cells 25:267-96. doi: 10.1146/annurev.immunol.25.022106.141609

25. Kilkenny C, Browne WJ, Cuthill IC, Emerson M, Altman DG (2010) Improving bioscience research reporting: the ARRIVE guidelines for reporting animal research. PLoS Biol 8(6):e1000412

26. Croci DO, Zacarias Fluck MF, Rico MJ, Matar P, Rabinovich GA, Scharovsky OG (2007) Dynamic cross-talk between tumor and immune cells in orchestrating the immunosuppressive network at the tumor microenvironment. Cancer Immunol Immunother 56(11):1687-1700

27. Rubinstein N, Alvarez M, Zwirner NW, Toscano MA, Ilarregui JM, Bravo A, Mordoh J, Fainboim L, Podhajcer OL, Rabinovich GA (2004) Targeted inhibition of galectin-1 gene expression in tumor cells results in heightened T cell-mediated rejection: a potential mechanism of tumor-immune privilege. Cancer Cell 5(3):241-251

28. Blidner AG, Salatino M, Mascanfroni ID, Diament MJ, Bal de Kier Joffe E, Jasnis MA, Klein SM, Rabinovich GA (2015) Differential response of myeloid-derived suppressor cells to the nonsteroidal antiinflammatory agent indomethacin in tumor-associated and tumor-free microenvironments. J Immunol 194(7):3452-3462

29. Reiche EM, Nunes SO, Morimoto HK (2004) Stress, depression, the immune system, and cancer. Lancet Oncol 5(10):617-625

30. Hammacher A, Thompson EW, Williams ED (2005) Interleukin-6 is a potent inducer of S100P, which is up-regulated in androgen-refractory and metastatic prostate cancer. Int J Biochem Cell Biol 37(2):442-450

31. Smith HA, Kang Y (2013) The metastasis-promoting roles of tumor-associated immune cells. J Mol Med 91(4):411-429

32. Shu ST, Martin CK, Thudi NK, Dirksen WP, Rosol TJ (2010) Osteolytic bone resorption in adult T-cell leukemia/lymphoma. Leuk Lymphoma 51(4):702-714 
34. Minn AJ, Gupta GP, Padua D, Bos P, Nguyen DX, Nuyten D, Kreike B, Zhang Y, Wang Y, Ishwaran H et al (2007) Lung metastasis genes couple breast tumor size and metastatic spread. Proc Natl Acad Sci U S A 104(16):6740-6745

35. Mihara S, Suzuki N, Wakisaka S, Suzuki S, Sekita N, Yamamoto S, Saito N, Hoshino T, Sakane T (1999) Effects of thyroid hormones on apoptotic cell death of human lymphocytes. J Clin Endocrinol Metab 84(4):1378-1385

36. Rosenquist R, Davi F, Stamatopoulos K (2013) Antigens in lymphoma development—current knowledge and future directions. Semin Cancer Biol 23(6):397-398

37. Dave SS, Wright G, Tan B, Rosenwald A, Gascoyne RD, Chan WC, Fisher RI, Braziel RM, Rimsza LM, Grogan TM et al (2004) Prediction of survival in follicular lymphoma based on molecular features of tumorinfiltrating immune cells. N Engl J Med 351(21):2159-2169

38. Carreras J, Lopez-Guillermo A, Fox BC, Colomo L, Martinez A, Roncador G, Montserrat E, Campo E, Banham AH (2006) High numbers of tumor-infiltrating FOXP3-positive regulatory T cells are associated with improved overall survival in follicular lymphoma. Blood 108(9):2957-2964

39. De Vito P, Incerpi S, Pedersen JZ, Luly P, Davis FB, Davis PJ (2011) Thyroid hormones as modulators of immune activities at the cellular level. Thyroid 21(8):879-890

40. Alamino VA, Mascanfroni ID, Montesinos MM, Gigena N, Donadio AC, Blidner AG, Milotich SI, Cheng SY, Masini-Repiso AM, Rabinovich GA et al (2015) Antitumor responses stimulated by dendritic cells are improved by triiodothyronine binding to the thyroid hormone receptor beta. Cancer Res $75(7): 1265-$ 1274

41. Namm JP, Li Q, Lao X, Lubman DM, He J, Liu Y, Zhu J, Wei S, Chang AE (2012) B lymphocytes as effector cells in the immunotherapy of cancer. J Surg Oncol 105(4):431-435

42. Keane C, Gill D, Vari F, Cross D, Griffiths L, Gandhi M (2013) CD4(+) tumor infiltrating lymphocytes are prognostic and independent of R-IPI in patients with DLBCL receiving R-CHOP chemo-immunotherapy. Am J Hematol 88(4):273-276

43. Juszczynski P, Ouyang J, Monti S, Rodig SJ, Takeyama K, Abramson J, Chen W, Kutok JL, Rabinovich GA, Shipp MA (2007) The AP1-dependent secretion of galectin-1 by Reed Sternberg cells fosters immune privilege in classical Hodgkin lymphoma. Proc Natl Acad Sci U S A 104(32):13134-13139

44. Gassmann P, Haier J (2008) The tumor cell-host organ interface in the early onset of metastatic organ colonisation. Clin Exp Metastasis 25(2):171-181

45. Bonzheim I, Geissinger E, Tinguely M, Roth S, Grieb T, Reimer P, Wilhelm M, Rosenwald A, MullerHermelink HK, Rudiger T (2008) Evaluation of FoxP3 expression in peripheral T-cell lymphoma. Am J Clin Pathol 130(4):613-619

46. Marzano AV, Vezzoli P, Fanoni D, Venegoni L, Berti E (2009) Primary cutaneous T-cell lymphoma expressing FOXP3: a case report supporting the existence of malignancies of regulatory T cells. J Am Acad Dermatol 61(2):348-355

47. Yano H, Ishida T, Inagaki A, Ishii T, Kusumoto S, Komatsu H, Iida S, Utsunomiya A, Ueda R (2007) Regulatory T-cell function of adult T-cell leukemia/lymphoma cells. Int J Cancer 120(9):2052-2057

48. Tadmor T, Fell R, Polliack A, Attias D (2013) Absolute monocytosis at diagnosis correlates with survival in diffuse large B-cell lymphoma-possible link with monocytic myeloid-derived suppressor cells. Hematol Oncol 31(2):65-71 
49. Capuano G, Rigamonti N, Grioni M, Freschi M, Bellone M (2009) Modulators of arginine metabolism support cancer immunosurveillance. BMC Immunol 10:1 